\title{
How and to which extent can the gas sector contribute to a climate-neutral European energy system? A qualitative approach
}

\author{
Christian Lebelhuber ${ }^{*}$ (i) and Horst Steinmüller
}

\begin{abstract}
Background: Mitigating climate change requires fundamentally redesigned energy systems in which renewable energy sources ultimately replace fossil fuels such as natural gas. In this context, the question how and to which extent the gas sector can contribute to an increasingly climate-neutral future EU energy system is heavily debated among scholars, energy industry experts, and policy makers.

Methods: We take a two-step approach: we begin with a review of studies from energy industry and academia to discuss potential gas sector contributions from a holistic energy system design point of view; this is followed by a comprehensive discussion of technical potentials, micro-economic conditions, and societal implications of renewable gas. We then enrich our findings with the results of an empirical focus group process.

Results: The gas sector can not only contribute to balancing volatile renewable energy production but also enable the supply of renewable energy to end-users in gaseous form; based on existing infrastructure. This could reduce costs for society, increase public acceptance, and ultimately speed up the energy system transformation. There is the theoretical technical potential to substitute major parts of natural gas with renewable gas of biogenic and synthetic nature. This, however, crucially requires a supportive policy framework like the one established for renewable electricity.

Conclusion: Given the societal benefits and the competitiveness of renewable gas as compared to renewable alternatives, energy policy makers should incorporate renewable gas and the existing gas infrastructure in the future energy system framework. The objective should be an optimized interplay of various energy vectors and their infrastructure along the entire energy supply chain. This requires a level playing field for different renewable technologies across different policy areas and a form of public support that strikes the balance between facilitating the gradual substitution of natural gas by renewable gas while maintaining public acceptance for this transformation despite higher costs for end-users.
\end{abstract}

Keywords: Energy system, Energy policy, Climate neutrality, Renewable gas, Biomethane, Power-to-gas, Technical potential, Support level

JEL classification: $013, \mathrm{Q} 42, \mathrm{Q} 48$

\footnotetext{
* Correspondence: christian.lebelhuber@jku.at

Energy Institute at Johannes Kepler University Linz, Altenbergerstraße 69,

4040 Linz, Austria
}

(c) The Author(s). 2019 Open Access This article is distributed under the terms of the Creative Commons Attribution 4.0 International License (http://creativecommons.org/licenses/by/4.0/), which permits unrestricted use, distribution, and reproduction in any medium, provided you give appropriate credit to the original author(s) and the source, provide a link to the Creative Commons license, and indicate if changes were made. 


\section{Background}

Europe's gas sector currently covers between 20 and 25\% of the overall European final energy demand [1]; its powerful high-pressure network has a length of 240, $000 \mathrm{~km}[2]$. But at first sight, the future of this potent industry sector seems dire: the climate-neutral energy system of the future appears to have no room for an entire sector that is traditionally oriented toward the fossil fuel natural gas. However, the gas sector with its extensive network and storage infrastructure might have a sustainable future beyond fossil fuels, beyond natural gas.

Indeed, this notion is already addressed in literature from different perspectives. There are papers such as Wall et al. or Götz et al. dealing with renewable gas production pathways $[3,4]$. The technical potential of these production pathways is also addressed by Baldino et al., Scarlat et al., and others [5, 6]. On the commercial side, papers such as Paturska et al., Thrän et al., and Papp et al. deal with the micro-economic conditions for renewable gas production in different settings [7-9]. While the scholarly discussion of renewables support policies is currently focused on electricity, the papers by Budzianowski et al. and Repele et al. provide some findings specifically for renewable gas, at least from a theoretical perspective $[10,11]$. Beyond that, there are various studies prepared or commissioned by academic institutions but also industry organizations close to the gas sector that outline the potential and economic benefits of renewable gas for different geographic scopes, for different energy end-use segments, and based on different assumptions with the presumed aim to raise awareness for these aspects among energy policy makers [12-16].

What is missing, however, is an integrative approach that brings together these various research streams to critically discuss how and to which extent the gas sector can contribute to an increasingly climate-neutral future European Union (EU) energy system. Applying, for the first time, such a holistic approach to the matter enables us to contribute to closing three major research gaps: (i) the specific functions and potential contributions of gas in a future EU energy system's supply chain, (ii) the required level of public support and resulting major societal implications of such gas sector contributions, and (iii) the implications that a future EU energy system including renewable gas has for policy making.

Specifically, this paper is the first theoretically guided compendium of potential contributions of the gas sector to the establishment of a climate-neutral EU energy system. These contributions have been identified based on a review of studies and analyses done by energy industry organizations and academia. To derive from such review implications of practical relevance for researchers and policy makers, it is complemented by a comprehensive critical discussion of the theoretical volume potential of renewable gases, an assessment of micro-economic conditions for the production of renewable gas, as well as its societal implications vis-a-vis alternative renewable energy production pathways. These consolidated findings are enriched by the empirical results of a focus group process with Austrian gas sector experts which took place in the context of the development of the Austrian government's climate and energy strategy for the period until 2030. This process, which could be equally expected also in other EU member states, delivered conclusions about enabling factors in energy policy, energy regulation, and beyond which are required for the gas sector to be able to deliver on its potential.

\section{Commitment to establish climate neutrality as a trigger for changing the EU energy system}

Already in 2011, the European Commission formulated the objective to reduce by 2050 their greenhouse gas emissions (GHGE) by at least $80 \%$ compared to the 1990 benchmark [17]. Simply spoken, this requires cutting GHGE by half in each decade to come [18]. However, since the European Union has committed itself to meeting the objectives of the Paris Agreement adopted in 2015 [19], the need for even stronger efforts has evolved. Consequently, the European Commission prepared in 2018 a new long-term vision toward achieving a climateneutral economy with net-zero GHGE by 2050 [20]. In this context, it is explicitly articulated that the energy end-use sector, which currently accounts for around $75 \%$ of total GHGE, will have to move toward climate neutrality. Such a net zero balance of associated GHGE can be realized by (i) avoiding emissions by replacing fossil fuels with renewable alternatives, (ii) eliminating emission of the predominant greenhouse gas by utilizing carbon dioxide in closed-loop industrial processes, or (iii) sequestering carbon dioxide for permanent storage in geological underground formations [20].

\section{Overall objectives for a future EU energy system}

Looking at GHGE reduction targets in isolation when defining measures to reconceptualize the energy system is insufficient. EU energy policy is based on the threefold aim of creating a sustainable, secure, and competitive system [21]. Consequently, climate neutrality may act as the immediate trigger for change, but the transition to and the maintenance of a sustainable future energy system must also provide for a maximum of costeffectiveness to ensure the affordability of energy for European consumers and the competitiveness of European businesses on the global market [22]. In this line of thinking, the notion of competitiveness is closely linked to sustainability: only a cost-effective and thus competitive system will be able to attract and maintain the level 
of public acceptance required for such a material longterm change. The same applies for security of supply.

Based on these fundamental objectives, there is broad consensus within European Union policy circles on several characteristics of the future EU energy system. Firstly, energy efficiency will be a pillar of the system. All sectors must undertake substantial efforts to increase energy efficiency [21, 23, 24]; this translates into the policy objective of reducing final energy demand by $20 \%$ by 2020 [25], and more than $30 \%$ by 2030 [26]. Secondly, fossil fuels as a primary energy source are not compatible with a climate-neutral energy system. Though natural gas can be a bridge fuel with comparatively little climate impact, the GHGE reduction targets can only be reached if we abandon, by 2050, all significant emissions from the use of fossil fuels [20]. This includes natural gas. Instead, primary energy needs to be provided from renewable energy sources (RES). The last decade has already seen substantial steps toward positioning renewable generation as centerpiece of the energy system, and there is a binding EU policy objective for the share of renewable energy to reach at least $32 \%$ by 2030 [27].

\section{Specific role of gas in a future EU energy system to be defined}

Beyond these basic features, the concrete way forward for achieving the policy goals and implementing changes to the energy system design is substantially less clear. A comprehensive Delphi survey about the future EU energy system with 450 experts formulated in 2016 the hypothesis of an "all-electric society" with electricity as single energy vector to emerge in the long run [28]. This, however, was recently scaled back by a study by the association of the European electricity industry which, in its most progressive scenario, expects electrification to not exceed $60 \%$ of total energy consumption. Also the 30th meeting of the European Commission's Gas Regulatory Forum (Madrid Forum) in October 2017 arrived at a different conclusion: The published minutes show that participants expect a dual energy system for the future, with a significant role of renewable gas alongside renewable electricity. They also stressed the need to implement cost-efficient measures, taking into account the value of the existing gas infrastructure [29]. This was confirmed by the European Commission's long-term vision for a climate-neutral economy, which was published in 2018 and which portrays an energy system integrating the various energy vectors, such as electricity and gas [20]. A study by the Council of European Energy Regulators (CEER) about the future role of gas from a regulatory perspective follows the same lines of thinking: In the interest of EU energy consumers and of a costeffective transition to a future energy system, the EU should make best use of the potentials of the gas sector
[22]. These include a finely meshed network that connects 118 million end-users ${ }^{1}$ within the Union [31], comprehensive storage infrastructure, and the potential to substitute natural with renewable gas [22]. But again, specific measures for how to realize this objective are not yet sufficiently agreed or even defined in detail.

\section{Methods}

In this paper, we apply a qualitative strategy. To identify and discuss the possible contributions of the gas sector in a structured way, we conducted a literature review of studies and analyses about the role of the gas sector in the energy transition. More specifically, we analyzed a sample of recently published papers to identify arguments in favor and against the potential contributions and functions of the gas sector. We used the following criteria to select the papers for our sample: (i) qualitative and/or quantitative assessment of renewable gases as part of an energy system; (ii) application of a climate scenario that requires a GHGE reduction of at least $80 \%$; (iii) geographic scope of at least one EU member state or the entire EU; (iv) consideration of at least one energy end-use sector; and (v) publication during the last 3 years. This resulted in a sample of 12 studies (see Table 1).

Half of the studies in the sample focus on Germany, where the extensive "Energiewende" debate has created substantial attention for energy system design issues. The other half of the sample is made up of studies dealing with the Dutch, French, British, and Austrian or overall EU situation, and which arrive at similar conclusions.

Publications in academic journals that would be relevant for the present review have been few and far between; to ensure that we take a comprehensive and upto-date view of the current discussion, the sample mostly includes studies from academic institutions, consultancies, industry organizations, etc. In addition, we used relevant findings from academic articles that cover specific aspects to enrich our review (see Table 2) and deliver on the discussion of technical potentials and micro-economic cost aspects of renewable gas.

Based on the review and its discussion, we addressed the enabling factors for the gas sector contributions previously identified. For this, we focused on Austria and based our work on the results and experience gained during a project carried out by the Energy Institute for the Austrian Association of Gas- and District Heating Companies. The Energy Institute set up a series of discussions with experts from the Austrian gas sector and social partners ${ }^{2}$ involved in energy policy making. The objective was the development of a joint position as input to the process of updating the national climate and energy strategy by the Austrian government [33]. We 
Table 1 Sample of studies reviewed $[8,12-16,34,44,52,54,63,72]$

\begin{tabular}{|c|c|c|c|c|c|c|}
\hline Title & Author & Year & $\begin{array}{l}\text { Geographic } \\
\text { scope }\end{array}$ & Sector(s) covered & Main conclusions & Ref. \\
\hline $\begin{array}{l}\text { Gas for Climate - How gas can } \\
\text { help to achieve the Paris } \\
\text { Agreement in an affordable way }\end{array}$ & van Melle, et al. & 2018 & EU & $\begin{array}{l}\text { Buildings, electricity, } \\
\text { industry, heavy duty } \\
\text { transport }\end{array}$ & $\begin{array}{l}\text { - Renewable gas production capacity } \\
\text { in the EU can reach a significant } \\
\text { level by } 2050 \text {. } \\
\text { - A future energy system including } \\
\text { renewable gas shows substantial } \\
\text { cost savings compared to a system } \\
\text { without renewable gas. }\end{array}$ & [12] \\
\hline Decarbonization Pathways & Eurelectric & 2018 & EU & Buildings, electricity, & - A future energy system & [34] \\
\hline
\end{tabular}

A 100\% renewable gas mix in Bouré et al. 2018 France $\begin{aligned} & \text { Buildings, industry, } \\ & \text { transport }\end{aligned}$

Energiemarkt 2030 und 2050-Der Beitrag von Gas- und Wärmeinfrastruktur zu einer effizienten $\mathrm{CO}_{2}$-Minderung (Energy market 2030 and 2050-The contribution of gas an heat infrastructure to an efficient $\mathrm{CO}_{2}$ reduction; authors' translation)

Der Wert der Gasinfrastruktur für die Energiewende in

Deutschland-Eine

modellbasierte Analyze

(The value of German gas

infrastructure - A model-based

analysis; authors' translation)

Green Gas Potential in ONTRAS Network Area
Hecking et al.

2017 Germany

2017 Germany

Bothe et al.

\author{
(n)
}

nymoen|strategieberatung 2017 Germany (regional) industry, transport

characterized by strong direct electrification (up to $60 \%$ of total demand), energy efficiency and further non-emitting allows to reach 95\% GHGE by 2050 .

- Despite a limited role of biomethane, particularly synthetic renewable gas plays a significant role (indirect electrification).

- Renewable gas (combination of biomethane and synthetic methane) could fully reduce natural gas by 2050 .

- The projected production costs for renewable gas are comparable to those for renewable electricity generation within a $100 \%$ renewable electricity scenario.

Heat, electricity, industry, transport

- A future energy system which still comprises gas and heat infrastructure shows substantial cost savings compared to a system focused on electrification and allows adjusting to technological developments more flexibly.

- A significant part of the renewable gas required for such an energy system design will be imported from outside the EU.

Buildings, industry, transport

- A future energy system with volatile renewables as predominant energy source relies heavily on gas storage to balance supply and demand.

- The additional use of the gas infrastructure to transport renewable energy in gaseous form to end-users shows major benefits and cost savings compared to an electricity-focused system.

Buildings, electricity, industry, transport

- A future energy system design strongly based on synthetic
Riesiges Potential an grünem Gas (Huge potential of green gas; authors' translation) methane produced from wind energy via power-to-gas shows costs similar to a system design oriented toward electrification.

- Beyond that, the gas-based design scenario shows various cost upsides and qualitative benefits.

- Renewable gas production capacity in Austria (predominantly for biomethane) can be expanded to a level that allows complete substitution of natural gas in the residential sector by 2050 .

- This avoids stranding of gas assets 
Table 1 Sample of studies reviewed [8, 12-16, 34, 44, 52, 54, 63, 72] (Continued)

\begin{tabular}{|c|c|c|c|c|c|c|}
\hline Title & Author & Year & $\begin{array}{l}\text { Geographic } \\
\text { scope }\end{array}$ & Sector(s) covered & Main conclusions & Ref. \\
\hline & & & & & $\begin{array}{l}\text { and ensures end-user gas prices } \\
\text { that remain competitive with alter- } \\
\text { native heating technologies while } \\
\text { being fully climate-neutral. }\end{array}$ & \\
\hline $\begin{array}{l}\text { Kalte Dunkelflaute — Robustheit } \\
\text { des Stromsystems bei } \\
\text { Extremwetter } \\
\text { (Dark doldrum — Robustness of } \\
\text { the electricity system during } \\
\text { extreme weather; authors' } \\
\text { translation) }\end{array}$ & Huneke et al. & 2017 & Germany & Electricity & $\begin{array}{l}\text { - Gas storage can be combined with } \\
\text { power-to-gas to provide an energy } \\
\text { system with high security of supply } \\
\text { even in extreme situations, while } \\
\text { the costs for society would remain } \\
\text { adequate. }\end{array}$ & [72] \\
\hline $\begin{array}{l}\text { Klimaschutz durch } \\
\text { Sektorkopplung - Optionen, } \\
\text { Szenarien, Kosten } \\
\text { (Climate protection trough } \\
\text { sector coupling - Options, } \\
\text { scenarios, costs; authors' } \\
\text { translation) }\end{array}$ & Ecke et al. & 2017 & Germany & Heat, electricity & $\begin{array}{l}\text { - The transition to a future energy } \\
\text { system should take a technology- } \\
\text { neutral approach to limit lock-in } \\
\text { effects. } \\
\text { - The gas sector has the potential to } \\
\text { contribute as a major flexibility } \\
\text { source and to enable cost savings } \\
\text { compared to an energy system } \\
\text { design without renewable gas and } \\
\text { gas infrastructure. }\end{array}$ & [63] \\
\hline $\begin{array}{l}\text { Erneuerbare Gase - Ein } \\
\text { Systemupdate der } \\
\text { Energiewende } \\
\text { (Renewable gases — updating } \\
\text { energy transition; authors' } \\
\text { translation) }\end{array}$ & Klein et al. & 2017 & Germany & $\begin{array}{l}\text { Heat, industry, } \\
\text { feedstock, transport, } \\
\text { electricity }\end{array}$ & $\begin{array}{l}\text { - The achievement of the } 2050 \\
\text { climate targets is only possible with } \\
\text { a future energy system design that } \\
\text { includes the gas infrastructure and } \\
\text { a significant level of renewable gas. } \\
\text { - This will also realize substantial cost } \\
\text { savings compared to a scenario } \\
\text { without a significant role of the gas } \\
\text { sector. }\end{array}$ & [16] \\
\hline $\begin{array}{l}\text { The Green Hydrogen Economy } \\
\text { in the Northern Netherlands }\end{array}$ & van Wijk & 2017 & $\begin{array}{l}\text { Netherlands } \\
\text { (regional) }\end{array}$ & $\begin{array}{l}\text { Industry, feedstock, } \\
\text { transport }\end{array}$ & $\begin{array}{l}\text { - The currently widely natural gas } \\
\text { based large-scale chemical industry } \\
\text { cluster in the Northern Netherlands } \\
\text { shall be transformed to a hydrogen } \\
\text { economy by around } 2030 \text {. } \\
\text { - This is based on a massive } \\
\text { development of especially wind } \\
\text { and power-to-gas capacity and } \\
\text { retrofitting natural gas pipelines to } \\
\text { transport pure hydrogen. }\end{array}$ & [52] \\
\hline H21 — Leeds City Gate & Sadler et al. & 2016 & $\begin{array}{l}\text { UK } \\
\text { (regional) }\end{array}$ & Heat, industry & $\begin{array}{l}\text { - The gas distribution system in the } \\
\text { city area of Leeds (approx. } 6 \text { TWh } \\
\text { annual consumption) shall be } \\
\text { converted to } 100 \% \text { hydrogen over } \\
\text { a three-year period. } \\
\text { - Hydrogen is produced through } \\
\text { traditional steam methane } \\
\text { reforming of natural gas delivered } \\
\text { as usual through the transmission } \\
\text { system. } \\
\text { - The carbon dioxide is sequestrated } \\
\text { deep under the North Sea. }\end{array}$ & [54] \\
\hline
\end{tabular}

can safely assume that comparable processes are also taking place in other countries, since the revised Directive on the promotion of the use of energy from renewable sources (Directive 2018/2001) requires member states to adopt national renewable energy action plans by 2020 [27].

Bringing in the social partners enriched the internal perspective of gas sector companies with expertise about the impact of energy strategies on the economy and society as a whole, without particular focus on the gas sector. The four discussion sessions that took place (see Table 3 for details) were prepared and moderated by the Energy Institute at Johannes Kepler University Linz. For the present paper, we performed a thematic analysis of the records of these discussions and of documents based on discussion results. 
Table 2 Articles dealing with specific aspects used to enrich the review results

\begin{tabular}{ll}
\hline Aspect & References \\
\hline Statistics and databases & {$[2,35,37,73,77]$} \\
$\begin{array}{l}\text { Renewable gas production } \\
\text { technology }\end{array}$ & {$[3,4,45,46,55,56,58,59]$} \\
Technical potentials & {$[6,7,49]$} \\
Economic considerations & {$[9,60,67]$} \\
Legal/regulatory background & {$[20,22,26,27,33,41,48,50$,} \\
Methane leakage & $78]$ \\
Energy storage technologies and & {$[34-76]$} \\
potentials & {$[36,38,39]$} \\
Hydrogen as an energy vector & {$[40,51,53,57]$} \\
Implications and developments & {$[64-66,69,70]$} \\
on end-user side & {$[42,43]$} \\
Electricity grid issues & {$[61,71,79,109]$} \\
Policy considerations &
\end{tabular}

\section{Results}

We start out with our results on the potential contributions of the gas sector to a future EU energy system and its functions therein. In a next step, this is complemented by empirically derived enabling factors for such contributions.

\section{Potential contributions of the gas sector to a future EU energy system based on the reviewed literature Arguments in favor of potential gas sector contributions}

Gas can serve as seasonal storage of renewable energy The electricity system requires a constant balance between generation and demand; there is very little potential for storing electricity on the network. As both the share of intermittent RES (such as wind and solar) and overall electricity demand increase, ${ }^{3}$ limited electricity system flexibility becomes an issue [12]. At the moment, it is generation capacity using fossil fuels that provides substantial system flexibility, but this will have to change in the long run due to the emissions it causes [20].

Often, pumped hydroelectric storage is hailed as climate-neutral solution to the flexibility issue, but its potential is limited. At the moment, pumped hydroelectric storage capacity in the EU amounts to $40 \mathrm{TWh}$, which equals approximately the average EU electricity

Table 3 Details of focus group sessions

\begin{tabular}{lll}
\hline Date & Number of participants & Participation of social partners \\
\hline Oct. 2017 & 6 & No \\
Dec. 2017 & 17 & Yes \\
Feb. 2018 & 15 & Yes \\
Apr. 2018 & 16 & Yes \\
\hline
\end{tabular}

demand over 5 days [35]. Even the absolute maximum theoretical potential of pumped storage capacity is no more than $123 \mathrm{TWh}$ [36].

Battery solutions for storing electricity are another option, but even though their efficiency increases and their cost declines rapidly, one of the studies we considered finds that they will not reach competitive investment cost levels by 2050 [12]. And even if they do, their selfdischarge characteristics limit their potential for seasonal storage [12, 16]. However, considering that 2050 is still a long way away and that there are intensive research efforts, this assessment might change.

Storing energy in the form of gaseous fuels, on the contrary, is an established gas sector practice for shortterm and, particularly, seasonal balancing needs. Existing gas storage infrastructure with an operational capacity of 1131 TWh [37] throughout Europe could be used to cover at least the seasonal storage demand that arises from the growing amounts of energy from renewable sources on the network [34, 38-40]. Also the gas network itself has large volumes of linepack at its disposal and can manage substantial pressure differences [34]. As we see, the gas network is easier to balance than the electricity networks and it the risk of end-user supply disruptions is lower [41].

Gas networks can reduce the need for electricity network expansion Recent electricity network expansion plans have faced difficulties [42] and involve large investments $[12,14,43]$. Further adapting the network to RES and an increased electricity demand will require further expansions at substantially larger scales [12, 34, 44]. Therefore, it appears rational to maximize use of any existing energy transport infrastructure, including the one for gas.

Both European policy makers and regulators widely support the view that strains on the electricity network could be relieved by transporting renewable energy to end-use destinations through the gas network [12, 15, 40, 44]. Some studies even consider this to be the gas sector's main contribution to societal cost savings in the transition to the future energy system $[12,14,16]$.

Replacing natural gas by renewable gas enables climate-neutral energy end use The reviewed studies underline that the technological solutions for replacing natural gas with renewable gases are already in place. These gases would only create as much GHGE as were captured during their production and thus allow all gas consumed in the EU to be climate-neutral by $2050[9,12,16]$.

Basically, renewable gases are produced either by turning biomass into biomethane or as synthetic fuels. The detailed technical characteristics of these technologies are beyond the scope of this paper, but we refer the 
interested reader to the papers of Wall et al., Schaaf et al., Bagi et al., and Götz et al., which provide reviews of research related to renewable gas production with a technology focus $[3,4,45,46]$. For this paper, we focus on the characteristics of these technologies from an energy system design point of view.

While the use of biomethane is limited by the availability of biomass resources and sustainability principles $[9,47,48]$, its long-term potential is often underestimated. Both policy makers and researchers rank the objective to create a circular economy highly. Such a circular economy implies extensive, cascading use of resources. This means that maximum value is to be extracted during usage, and residues are used for energy generation in a last step, but again at a maximum level $[3,49]$. The European Commission has translated this vision into a zero waste program for Europe [50]. However, frequently used estimations of biomethane potentials tend to be based on a mindset which is not sufficiently coherent with these principles and are assumed to have a substantial upwards potential (see "Technical potential for renewable gas production" section for a discussion of the technical potential). Considering the current overall EU import dependence beyond $50 \%$ and political objective to reduce this, decentralized, local biomethane production could support the achievement of this objective [12, 13]. This would also create new jobs and strengthen the rural economy [3, 12].

As already mentioned, renewable gases can be of biogenic origin but can also be produced synthetically, most prominently through power-to-gas. This latter technology uses, e.g., water electrolysis to convert RES electricity first into renewable hydrogen and then, possibly, into synthetic renewable methane. It not only enables using excess RES generation instead of curtailing it [34, 44] but also unlocks roles for the gas infrastructure beyond pure storage. Hydrogen and synthetic renewable methane could become gaseous "energy vectors" to meet any final energy need based on renewable sources such as wind and solar $[12,16,44,51]$. This particular avenue is envisaged by the initiative to turn the large-scale chemical cluster in the northern Netherlands into a hydrogen economy [52].

Hydrogen may also be produced based on fossil fuels and different technologies, such as it is currently done in the chemical industry [53]. In the context of a climateneutral energy system, the resulting carbon dioxide then needs to be either permanently utilized or stored so that it does not enter the atmosphere [20]. This is planned for the H21 project in Leeds, where carbon dioxide will be compressed and sequestrated deep in the North Sea [54]. Another technological perspective for the future production of hydrogen is the pyrolysis process [55], which is investigated as potential future strategy by the major Russian gas supplier Gazprom [56].

While natural gas networks might be turned into pure hydrogen systems [54], the potential to blend hydrogen into the existing natural gas system is limited to singledigit percentage shares [12, 44, 51]. Higher percentages would require some adaptation of network infrastructure and end-use appliances [12, 57]. This is not the case for synthetic renewable methane. While its production, through methanation of renewable hydrogen, implies additional investments and conversion losses, it delivers a range of benefits: From a chemical point of view, it is almost identical to natural gas and thus requires no adaptation of network infrastructure or end-use appliances. Also, it can utilize carbon dioxide emissions from combustion processes or biomethane production in circular processes or reduce the amount of carbon dioxide in the atmosphere through direct air capturing $[8,12,15,58,59]$.

Beyond the intra-EU potential for the production of renewable gas, there is also the possibility to import renewable gases $[12,15,60]$. The study by van Melle et al. looks at Ukraine and Belarus, which are close to EU markets and well connected through existing pipelines. It finds that these two countries alone could provide an additional $20 \%$ on top of the intra-EU production potential [12]. Hecking et al. and Bothe et al. also refer to the comparative cost advantages of production regions outside the EU and expect major imports in the long run $[14,15]$.

Irrespective of the specific origin of renewable gas, it can be used to meet various final energy needs [40]. While the extent to which renewable gases offer advantages over alternatives differs between sectors, there are potentials in all end-use segments. In transport, gas plays a minor role for the time being, and public acceptance is low [61, 62]. However, over time, renewable gas could develop into a relevant substitute for traditional liquid fuels and could help reduce transport-related GHGE; the vision for it exists, as does the technology needed to make it happen [40]. This option is particularly relevant for heavy-duty road transport, where electric drives face technological limits [12, 61].

The buildings sector, on the contrary, is still mostly based on fossil fuels in general and natural gas in particular [34]. Consequently, this sector is considered to be highly important for determining the role of gas in the future $[8,12,15,44]$. While renewable district heating and electric heat pumps are often discussed as prime means of reducing GHGE in this sector [12], the studies we reviewed argue that renewable gas can make a beneficial contribution to a future energy system in this sector also $[8,12,14,15]$. Proponents argue that, beyond the economic considerations of building owners in the context of heating system 
adaptations, continued use of existing gas infrastructure in the public domain would create added value for society as a whole $[8,12-15,44,52,54,63]$.

The industry faces yet another different set of challenges. There are technological limitations to the direct use of electricity in high-temperature processes [12, 14, 34]. Nonetheless, the European steel-making industry, currently a major gas consumer, is exploring ways to electrify energy-intensive processes, e.g., by using electric arc furnaces instead of traditional blast furnaces [64]. Such research and development could lead to the technical limitations of electrification being overcome over time [65]. We cannot know yet how this would affect the competitiveness of the European industry on the global market [66].

The position of gas as a fuel for electricity generation directly depends on the intended phase-out of coalbased generation. In such a context, gas-fired generation could be a logical source of system flexibility that would help balance a RES-dominated electricity system [34]. In a largely climate-neutral energy system, however, the fuel used will have to be biomethane or be based on the power-to-gas-to-power cycle [34, 63]. To maximize energy efficiency, resulting waste heat should also be used.

Utilization of readily available gas infrastructure requires little investment Given the fact that the natural gas infrastructure is already in place, renewable gases could be transported without large-scale gas network expansion. But making the gas networks ready for renewable gases, particularly hydrogen, will require some adaptation. A study that investigates in detail the cost of such adaptions in the German gas network concludes that it will be at a level of $25 \%$ of the replacement investment costs that are required to maintain the capacity of the network in any case [67]. Beyond that, further necessary investments would be limited to connecting a significant number of biomethane production plants and power-to-gas facilities [12], which we do not expect to be significant [13].

Another feature of the European gas network and its major transit pipelines is the high level of interconnectivity between member states [52]. This could facilitate widespread use of renewable gas within the Union and provide efficient access to different potential production sources of renewable gas across the EU [15].

The gas sector can speed up the transition to a future energy system The studies we analyzed argue that a combination of increasing renewable electricity generation and a well-defined involvement of the gas sector can speed up the transition to a climate-neutral energy system [12]. Looking at renovation rates, which are currently particularly low, ${ }^{4}$ even just insulating residential buildings to the degree required for a transition to electric heat pumps would take decades. The same is assumed for central heat networks in buildings on a large scale [12]. If end-users continue using gas-fired appliances based on renewable gas, this could significantly speed up the transition [14]. This also holds true for industrial processes where alternatives to gas in some cases rarely exist or would require lengthy research and transformation processes [12, 14, 16, 34].

A gas sector contribution to a future energy system can mitigate public acceptance issues Local resistance to large-scale renewable generation capacity construction can be substantial [69]. Also, the overhead lines common in electricity transmission are often perceived negatively by the affected local communities [12, 70]. And the public debate will not be long in picking up that an electricity-dominated energy market design will create the need for substantial expansions of the electricity distribution network also [15, 34, 44]. This contrasts with the gas infrastructure, which is already in place [12, 44]. Also, gas networks are mostly underground, so public acceptance is less of an issue [15].

Acceptance is important not just for infrastructure projects but also for activities on the end-user side, such as replacing heating systems and/or insulating buildings. The significance of these activities and the related costs go beyond societal considerations; indeed, they can be expected to be decisive for the long-term sustainability of policy objectives and measures directed at operationalizing climate targets $[15,69]$.

A gas sector contribution to a future energy system can foster security of supply Renewable gases can be particularly valuable when it comes to maintaining a high level of security of supply $[15,44]$ : An energy system with multiple energy vectors is less concentrated and therefore more flexible in stress situations $[14,44,71]$.

A gas sector contribution to a future energy system can ensure cost effectiveness from a societal perspective The studies we analyzed demand a holistic view of the energy system cost that results from the system's overall architecture and from the role it attributes to the gas infrastructure and renewable gases $[12,15,44$, 63]. All arguments in favor and against the potential role of gas need to be factored in when modeling societal cost implications. This should then be the basis for policy making $[12,15,44,63]$.

We recognize that the analyzed studies have limited comparability in terms of the scenarios and end-use sectors considered, the assumptions, the geographical scope, the assessment methodology, etc. However, they all model the societal cost implications of an energy 
system that includes renewable gases compared to an alternative system design with electrification of major parts of the energy supply chain. Examining these results in an integrative way shows that gas sector contributions can have substantial overall cost benefits.

One group of studies researches the impact of renewable gases based on the assumptions that power-to-gas uses domestic RES excess generation only and that considerable or even extensive volumes of biomethane are produced domestically. According to van Melle et al., who take the EU as geographic scope, this can create societal cost savings of $€ 138$ billion per year by 2050; these are mainly generated as investments toward adapting residential heating concepts and massively expanding RES generation capacity and electricity networks become redundant [12]. These estimates are corroborated by Eurelectric, who expect that average annual investments at a level of $€ 90$ to $€ 110$ billion will be necessary to expand renewable generation and transmission capacity in an electricity-focused system [34].

Bothe et al. and Ecke et al. follow a similar reasoning, estimating societal cost savings in Germany by 2050 at $€$ 12 billion [15] and $€ 4$ billion per year [63], respectively. Also Huneke et al., with their focus on the interrelation between flexibility/storage options and the demand for RES generation capacity, postulate that the use of powerto-gas in combination with seasonal gas storage can provide an energy system with high security of supply at adequate societal costs, even in extreme situations [72].

Another group of studies does not limit power-to-gas to excess RES but considers RES generation capacity and the related use of power-to-gas as an endogenous result of overall energy system optimization. They expect the additional investments in RES generation capacity and the transformation losses from extensive power-to-gas use to be more than outweighed as the need for electricity transmission network expansion is reduced, less flexibility in the form of battery storage and gas-fired generation capacity is needed, and additional investments in a heat sector that remains partly gas-based become redundant. Klein et al. suggest total societal cost savings for Germany of $€ 19$ billion until 2050, even though they leave aside the additional upsides of the savings in expansion of the electricity distribution network and the advanced utilization of biomethane potentials [16]. This conclusion is supported by nymoen with similar results [44].

A third category of studies formulates the central expectation that a major share of renewable gases will be imported from outside the EU. Despite the costs for these imports, Hecking et al. estimate societal cost savings for Germany to amount to $€ 129$ billion until 2050, arguing along the same lines as the above studies. In particular, they cite redundant investments into gas-fired generation capacity, redundant replacement of appliances and building insulation by end-users, and reduced costs for electricity network expansion and imports; they do not even monetize adaptations by industrial endusers and a potential dismantling of infrastructure, which could further support the overall result [14].

\section{Arguments against potential gas sector contributions} Gas-based energy end use is often less efficient than alternatives With regards to the residential sector, electric heat pumps are considered to be the potentially predominant technology for replacing gas-fired appliances $[12,44]$. The reviewed studies acknowledge that such heat pumps are already substantially more efficient than gas-fired boilers or conventional electric heating systems and that they develop rapidly [12, 15, 34]. In contrast to gas-fired boilers, however, heat pumps deliver lowtemperature heat which requires specific heat delivery systems (mostly floor heating) and proper building insulation [16]. Also, heat pumps are highly efficient on average, but their specific efficiency directly correlates with the outside temperature, i.e., heat pumps consume most electricity in periods of high peak load. This needs to be accommodated in the electricity network. Consequently, a substantial increase of the share of heat pumps, e.g., in residential heat delivery will improve the efficiency of end-use heat generation but will create issues and costs further up the supply chain $[16,63]$. This is especially true where buildings that are currently heated with natural gas need to be adapted for heat pumps $[15,44]$.

The efficiency argument is valid beyond the residential sector also. A typical example is industrial hightemperature heat, which is largely gas-based also for efficiency reasons $[34,63]$.

Methane leaks into the atmosphere The International Energy Agency reports that methane to the amount of $1.7 \%$ of global natural gas consumption currently leaks into the atmosphere [73]. Given the fact that methane as greenhouse gas is several times more harmful than carbon dioxide, this drives global warming beyond proportion $[6,74]$. While methane leakage occurs along the entire gas supply chain, most of it can be attributed to production and processing as well as the long-distance transport of natural gas [74]. Replacing natural gas delivered to Europe from distant sources by renewable gas produced within the EU or nearby could improve the situation [73]. A recent study with a focus on methods to determine methane emissions in EU gas distribution systems finds that less than $10 \%$ of total methane emissions by EU member states are actually the result of methane leaks, while the largest culprits are the agriculture and waste sectors [75]. Nonetheless, against the 
background of a climate-neutral energy system, this issue should be considered with caution. Since from a technical perspective, it is almost impossible to fully eliminate all fugitive methane emissions of the methane supply chain, the gas sector should set up coherent measurement standards and methods to ensure transparency [75], and continue to minimize such emissions to the extent possible $[74,76]$.

Biomethane production may raise sustainability issues Biogas and biomethane production have been criticized for displacing food and feed production, for negative effects on land use, and for harming biodiversity or soil quality [12]. This is a crucially important argument, since the prioritized use of RES must not sacrifice the high-level principle of strengthening our economy's sustainability.

To counter these effects, the European Union has just tightened mandatory sustainability criteria for biofuels [27]. In addition, national measures can be passed to ensure that the primary source of feedstock is in line with sustainability principles [18]. To avoid any ambiguity related to the sustainability of biomethane, even if produced in compliance with the applicable standards, some of the studies we analyzed take an alternative approach and do not consider energy crops as feedstock at all $[8,13]$. This is closely related to the circular economy objective addressed earlier in this paper.

\section{Enabling factors for gas sector contributions to a future EU energy system}

After having discussed arguments in favor and against the gas sector as part of a climate-neutral EU energy system in the previous chapter, we focus on the specific enabling factors for such a contribution in this subchapter. The results we present here were developed in a focus group process that was conducted to input to the Austrian climate and energy strategy by outlining the potential role of the gas sector in this overall future concept. The focus group comprised experts from the Austrian gas sector and social partners involved in energy policy making (see "Methods" section for details). The considerations and arguments presented are based on the assumption by Papp et al. that the Austrian gas sector could gradually replace at least $23 \mathrm{TWh}$ of natural gas by renewable gas by 2050 [8]. This represents around $25 \%$ of the current total natural gas demand [77] and allows for covering the entire gas demand of the residential sector by that time. The focus groups concentrated on the changes to the current energy system framework that are required to realize this capability. We therefore consider them as enabling factors for such a gas sector contribution to a climate-neutral energy system. We outline them in the following.
Commercial support scheme for renewable gas production All participants in the discussions agreed that GHGE abatement costs related to the use of RES in general and the use of renewable gases in particular are not sufficiently reflected in current energy market prices. There was general agreement that public support schemes of substantial extent will be required to actually move development towards climate neutrality. This is also crucial for renewable gas production technologies.

Such support schemes should especially involve feedin tariffs or feed-in premiums over a period of at least 10 years. Lately, there has been a move toward marketbased determination of support levels [27, 78, 79]. To account for this development, auctions should be established for this purpose. They should be run by a responsible authority ("auctioning/clearing authority") and be based on the intended penetration path of renewable gas. This is expected to create favorable and predictable investment conditions and facilitate renewable gas production. In addition, the support scheme should differentiate between renewable gas production technologies to reflect their different potentials and different technology readiness levels.

\section{Fair financing of support instruments}

In principle, the support scheme should be financed through a dedicated component of the gas network tariffs that is levied on consumption and payable by gas end-users. Participants considered this to be important to avoid undue cross-subsidies; also, a similar non-tax levy already applies for electricity.

There was controversy about which groups of gas customers should have to pay such a support levy. While the general concept aimed to position renewable gas in the buildings sector, this differentiation can hardly be made from a technical/organizational point of view. This led to different views about whether the support levy should only apply to residential end-users of gas and small and medium-sized enterprises (SMEs), both connected to the low-pressure level, or whether gas consumers with larger consumptions (connected to higher-pressure levels), such as the industry, should also have to pay. This was considered a crucial issue. In contrast to electricity, which can hardly be substituted by end-users, gas competes with other (fossil) energy carriers. Therefore, allocating the cost incurred by the support scheme for renewable gas producers needs to strike the right balance between broad socialization and protection of particularly price-sensitive end-users. This is considered important for maintaining competitiveness of businesses and energy affordability throughout the population [66]. 


\section{Level playing field for all renewable energy vectors on the end-user side}

All participants agreed that the public image of renewable gas and awareness in relation to its positive impact need to be improved to realize the identified potentials. In particular, renewable gas should be considered in housing subsidy schemes and building regulation. For instance, gas-fired heating systems should not automatically be considered to be fossil-fuel based and thus be banned from new buildings or renovation of existing ones (as is the case for oil [33]). Instead, depending on the actual level of renewable gas injected into the system as a result of the support scheme, gas-fired heating should be considered renewable. In line with the principle of technology neutrality, heating installations based on renewable gas should receive the same housing subsidies as other renewable heating systems.

The discussion revealed different options for operationalizing such a model. In principle, however, there needs to be an auctioning/clearing authority that organizes the auctions and acts as contract partner for renewable gas producers for the entire support period. Additionally, this entity should transfer ownership of the volume of renewable gas that producers inject into the network to gas suppliers. In doing so, priority should be given to suppliers of gas end-users who receive housing subsidies. Such end-users need to provide proof that they are using renewable gas so as to remain eligible for their housing subsidies; this proof could either be provided through direct cooperation between the auctioning/clearing authority and the public institution responsible for housing subsidies ("housing subsidy authority") or by the end-users using guarantees of origin provided by their suppliers. This could be easily achieved since a guarantees of origin scheme for electricity, gas, heating, and cooling delivered to end-users must be established by mid-2021 in any case [27]. With regards to commercial settlement, suppliers would pay the auctioning/clearing authority the market price for the volume they receive. The support levy would be collected from gas end-users by network operators and transferred to the auctioning/clearing authority to compensate it for the support paid to renewable gas producers (beyond the market price). Figure 1 provides an illustration of this process.

\section{Legal clarifications}

There was agreement that supporting renewable gases requires a universal legal definition of renewable gases; the relevant legislation at European and national level does not provide sufficient definition at the moment. For legal and regulatory purposes, it must also be clarified whether and in which way existing tariff and taxation components apply to new renewable gas production technologies.

\section{Innovation incentives}

Participants agreed that public support for renewable gases should also extend to research and development which is necessary to facilitate innovations in all relevant areas. By way of example, the Northern Netherlands Initiative aims to help establish hydrogen innovation centers to develop technologies and business concepts, as well as to educate the workforce and the public.

\section{Discussion}

In order to achieve the GHGE reduction goals laid down in the Paris Agreement, the EU energy sector will have to undergo a substantial transformation and become virtually climate-neutral by 2050 . Fossil fuels need to be phased out gradually, energy efficiency measures must take effect, and renewable generation capacity must be expanded substantially.

Our review of relevant studies mostly reveals arguments in favor of gas sector contributions, assuming that it can facilitate the transition to a climate-neutral European energy system and be a long-term element in it. More precisely, the role of the gas sector need not be limited to balancing renewable electricity generation and demand through power-to-gas and the existing gas infrastructure. Renewable gas produced from renewable electricity as well as an optimized use of biomass in a circular economy could support climate-neutral energy end use through the utilization of existing infrastructure in the public domain (networks, storages) and through existing end-use appliances (combustion and heating systems, etc.). This appears to be in line with the views of European policy makers and regulatory bodies [20, 22 ] as well as the industry association of the European electricity industry [34].

However, renewable gases play a minor role for the time being. With $19 \mathrm{TWh}$ of injection into the gas grid by 540 plants in 15 European countries [80], biomethane represents less than $1 \%$ of total EU gas consumption [81]. For power-to-gas, the current focus of the 128 installations in 16 European countries is clearly on research and their contribution to European gas supply is, for the time being, negligible [82].

The reviewed studies argue that the technologies to produce renewable gas of both biogenic and synthetic nature are already in place. However, it can be assumed that broad market penetration requires not only sufficiently developed technological solutions but also the actual technical potential in terms of resources, feedstock, etc. as well as a favorable policy framework and sufficiently attractive micro-economic conditions for investment into renewable gas production. To address this 


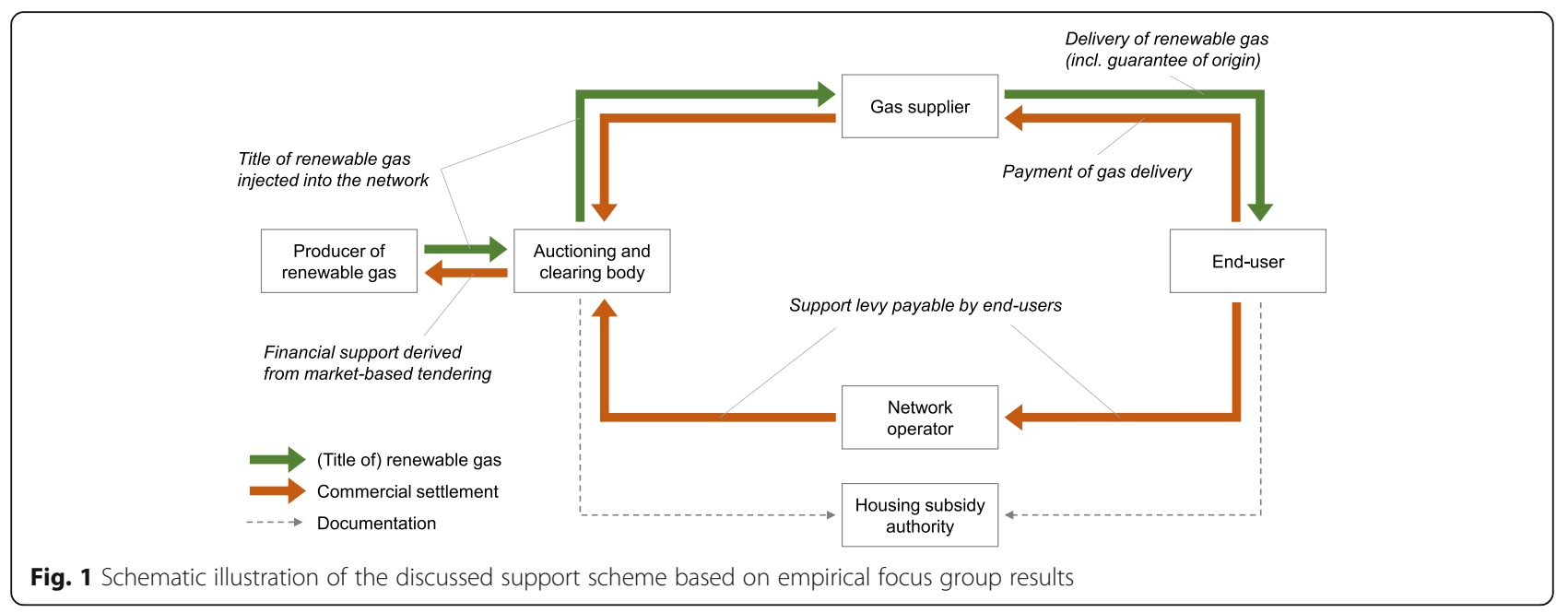

aspect, we discuss the technical potential for renewable gas production and its micro-economic conditions in greater detail below, including its societal implications. By doing so, we do not provide an overall optimization of the energy system or indicate the optimal share of renewable gas in technical or economic terms. Rather, we derive the above-mentioned characteristics of renewable gas from various sources and bring them into an integrated energy system perspective, including the volume and cost side and a comparison with renewable electricity. This aims to take the academic debate of renewable gases to the next level and to support energy policy makers.

\section{Technical potential for renewable gas production}

Due to significantly different technological avenues for the production of biogenic and synthetic renewable gas, we differentiate our discussion of potentials accordingly. For biomethane, we must bear in mind that the vast majority (89\%) of the biogas produced is not currently upgraded to biomethane and injected into the gas network, but rather used on-site for electricity and/or heat production [83]. This, however, is mainly the result of national support policies incentivizing especially use in the electricity sector [83].

In its assessment of the potential of biogas in the EU beyond 2020, the European Commission includes a scenario of priority gas grid access for biogas [83]. Literature provides various arguments in favor of gas grid injection, such as (i) that biogas can replace fossil fuels in applications where other renewable alternatives are scarce [83], (ii) that biomethane is very flexible because it can be easily stored in gas storage facilities and distributed via the gas grid [5], and (iii) that biomethane offers much better end-use efficiency ${ }^{5}$ than on-site electricity generation based on raw biogas [7, 84].
We refer to existing literature to assess technical biomethane potential. It is important to note that we do not consider the absolute amount of biomass residues theoretically available for biomethane production but only those volumes explicitly classified as biomethane. Since biogenic origin does not in itself ensure that potentials are used sustainably in a broader context, and since there are concerns related to biogas/biomethane (for further details, see "Arguments against potential gas sector contributions" section and the papers by Scarlat et al. and Boulamant $[5,85])$, we leveraged the level of detail provided in the relevant literature to exclude at least potentials that are predominantly based on energy crops as a feedstock. Instead, we focus on sewage sludge and particularly residues form the agricultural, forestry, industry, and municipal sectors.

Table 4 provides an overview of the biomethane potentials estimated in literature for the years 2030 and 2050. We compare these potentials with the officially projected EU gas demand for these years [88]. According to these results, biomethane could cover between 11 and $55 \%$ of the projected total EU gas demand by 2050 . In this context, it is worthwhile considering the structural configuration of the gas network. The transmission network is operated at high pressure and enables large volume transit, cross-border interconnection, and supply to distribution networks; only the largest end-users, such as gas-fired power plants and heavy industry, are directly connected to this network level [89]. The majority of gas end-users, such as households and SMEs, are connected to the distribution level. Biomethane will be predominantly injected into this distribution network [89].

Figure 2 shows the long-term average share of household gas consumption in total gas consumption at $44 \%$. If we assume that this share stays the same in 2030/2050 (at a time when, according to official projections for both years, total gas consumption will be down by only 
Table 4 Technical biomethane potentials for 2030/2050 in relation to projected total EU gas demand (based on [5, 6, 12, 47, 83, 8688])

\begin{tabular}{|c|c|c|c|c|c|c|c|c|}
\hline Source/scenario & Ref. & $\begin{array}{l}\text { Bio-methane } \\
\text { potential } \\
2030 \text { (TWh) }\end{array}$ & $\begin{array}{l}\text { Gas demand } \\
2030 \text { based on } \\
\text { EU28 reference } \\
\text { scenario (TWh) }\end{array}$ & $\begin{array}{l}\text { Share of total } \\
\text { demand possibly } \\
\text { covered by } \\
\text { biomethane in } \\
2030\end{array}$ & $\begin{array}{l}\text { Bio-methane } \\
\text { potential } \\
2050 \text { (TWh) }\end{array}$ & $\begin{array}{l}\text { Gas demand } \\
2050 \text { based on } \\
\text { EU28 reference } \\
\text { scenario (TWh) }\end{array}$ & $\begin{array}{l}\text { Share of total } \\
\text { demand possibly } \\
\text { covered by } \\
\text { biomethane in } \\
2050\end{array}$ & Remarks \\
\hline Baldino et al. & {$[6]$} & 170 & 2803 & $6 \%$ & 290 & 2752 & $11 \%$ & $\begin{array}{l}\text { Only sustainable } \\
\text { feedstock considered }\end{array}$ \\
\hline $\begin{array}{l}\text { European } \\
\text { Commission }\end{array}$ & {$[83]$} & 360 & & $13 \%$ & n.a & & n.a. & $\begin{array}{l}\text { Technological focus } \\
\text { on digestion process, } \\
\text { gasification out of } \\
\text { scope }\end{array}$ \\
\hline $\begin{array}{l}\text { Mathiasson. (only } \\
\text { digestion) }\end{array}$ & {$[47]$} & 300 & & $11 \%$ & n.a & & n.a. & $\begin{array}{l}\text { Technological focus } \\
\text { on digestion process, } \\
\text { gasification out of } \\
\text { scope }\end{array}$ \\
\hline $\begin{array}{l}\text { Mathiasson } \\
\text { (digestion and } \\
\text { gasification) }\end{array}$ & {$[47]$} & 500 & & $18 \%$ & n.a & & n.a. & $\begin{array}{l}\text { Consideration of both } \\
\text { digestion process and } \\
\text { gasification technology }\end{array}$ \\
\hline Scarlat et al. & {$[5]$} & 300 & & $11 \%$ & 510 & & $19 \%$ & $\begin{array}{l}\text { Only residues and } \\
\text { sewage sludge are } \\
\text { considered; } 2050 \text { value } \\
\text { represents full technical } \\
\text { potential }\end{array}$ \\
\hline Searle et al. & {$[86]$} & n.a. & & n.a & 360 & & $13 \%$ & $\begin{array}{l}\text { Only residues are } \\
\text { considered }\end{array}$ \\
\hline van Melle et al. & [12] & n.a. & & n.a & 980 & & $36 \%$ & $\begin{array}{l}\text { Incl. cover crops based } \\
\text { on sequential cropping } \\
\text { strategies }\end{array}$ \\
\hline $\begin{array}{l}\text { Kovacs et al. } \\
\text { (without energy } \\
\text { crops) }\end{array}$ & {$[87]$} & 340 & & $12 \%$ & 1030 & & $37 \%$ & $\begin{array}{l}\text { Only residues are } \\
\text { considered }\end{array}$ \\
\hline $\begin{array}{l}\text { Kovacs et al. (incl. } \\
\text { limited energy } \\
\text { crops) }\end{array}$ & {$[87]$} & 500 & & $18 \%$ & 1510 & & $55 \%$ & $\begin{array}{l}\text { Additional scenario } \\
\text { including most } \\
\text { conservative energy } \\
\text { crops potential }\end{array}$ \\
\hline
\end{tabular}

10\% approximately from 2016 levels [88]), this adds a new perspective which is illustrated with Fig. 3. The technical biomethane potential in 2050 could cover between 24 and $100 \%$ of household gas consumption. Notwithstanding the need for seasonal balancing, this could go a long way toward uncoupling the distribution level from the transmission network, which serves as the main supply route today. While we expect potentially significant national differences, which could be addressed by further research at country level, this could indeed be a significant step toward achieving the policy objectives of climate-neutral energy supply and reduced import dependence $[20,21]$. This conclusion coincides with the empirical results presented in "Enabling factors for gas sector contributions to a future EU energy system" section which also envisage that natural gas supplied to Austrian households will ultimately be substituted by renewable gas; being predominantly biomethane [8].
With regards to synthetic renewable gas, the assessment of the technical potential follows a different logic. In contrast to the feedstock for biomethane production (i.e., biogenic residues/biomass), the predominant RES for powerto-gas applications (solar and wind energy) are nearly inexhaustible. Consequently, the only limits that apply on the pure technical potential for synthetic renewable gas are (i) land-use restrictions for, e.g., wind and solar installations which limit the amount of renewable electricity that can be generated $[44,90,91]$, (ii) the availability of electrolysers as part of a supply chain that is growing $d y-$ namically but even so, is only just developing [92], and (iii) limited carbon dioxide supply for producing synthetic methane $[58,91]$. The effective technical potential, however, will rather result from the overall energy system design. The most relevant parameters in this context are expected to be the share of volatile renewable generation, the degree of electricity network expansion, excess generation curtailment principles, etc. [12, 15, 93]. In addition, 


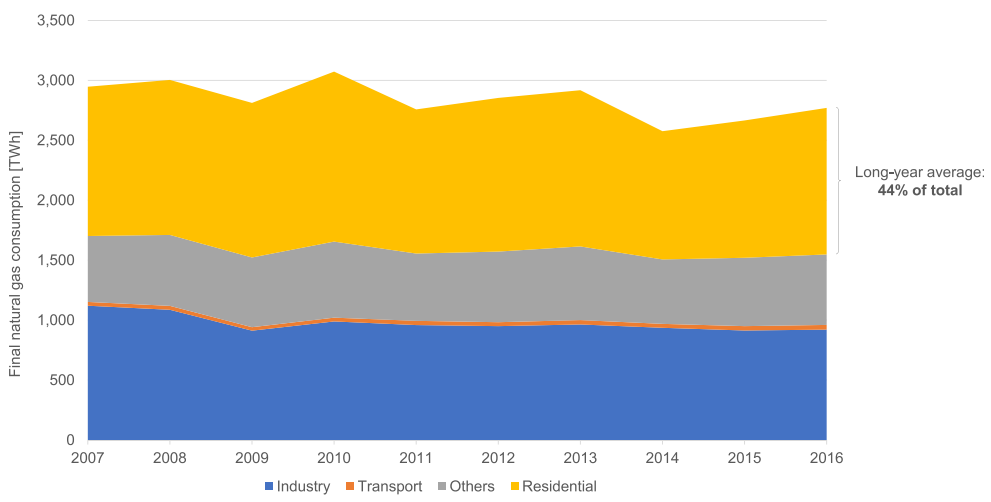

Fig. 2 Historical EU natural gas consumption per sector (based on [81])

structural parameters such as interconnection capacity between markets, the potential for carbon dioxide storage, etc. will weigh in [93-95]. Consequently, the effective technical potential is case-specific. Blanco et al., in their recent paper, use a scenario-based approach to model the potential of synthetic renewable methane in a largely climate-neutral EU energy system. This allowed them to vary key parameters across their 120 scenarios, accounting for different circumstances (such as those outlined above) [96]. With regards to the effective technical potential, they report an endogenously derived EU power-to-gas capacity of up to $546 \mathrm{GW}$ [96]. Considering that the natural gas import capacity from non-EU countries and LNG terminals currently available amounts to approximately $900 \mathrm{GW}$, this power-to-gas capacity is substantial.
Micro-economic conditions for renewable gas production After having discussed the volume potential of different types of renewable gases to substitute natural gas from a technical perspective, we now turn to the microeconomics of renewable gas production. This is crucial, since actual market penetration of renewable gases will require that they are able to compete with alternatives [97]. In order to assess to which extent this is and will be the case, we extracted production cost estimates for the different renewable gases discussed in this paper from existing literature (see Table 5). Please note that we understand production costs as full costs that include the cost for production of biogas, its upgrading into biomethane, and its injection into the gas network.

Given the variety of assumptions, technologies, plant sizes, investment cost and conditions, feedstock choices,

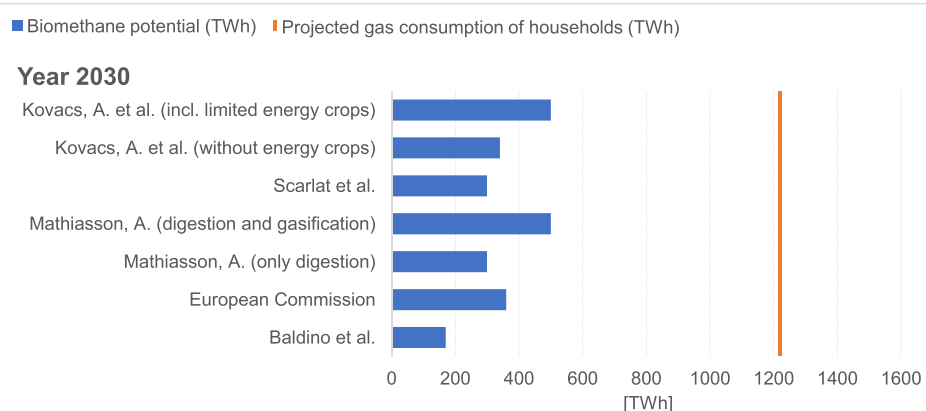

Year 2050

Kovacs, A. et al. (incl. limited energy crops)

Kovacs, A. et al. (without energy crops)

van Melle, T. et al.

Searle et al.

Scarlat et al.

Baldino et al. [TWh]

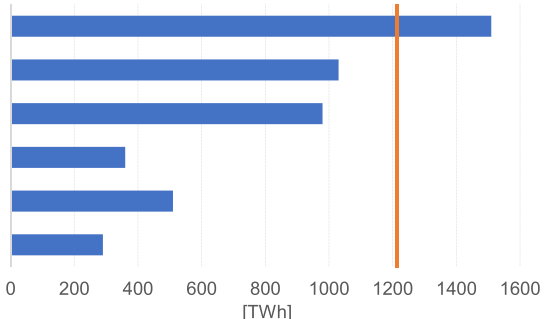

Fig. 3 Technical biomethane potentials in the EU for 2030/2050 in relation to projected households gas consumption (calculations based on data from Table 4 and [81, 88]) 
Table 5 Overview of production cost estimates for renewable gases (based on $[7-9,11,12,52,60,83,95,110]$ )

\begin{tabular}{|c|c|c|c|}
\hline Source & Ref. & $\begin{array}{l}\text { Full cost of production } \\
(€ / M W h)\end{array}$ & Remarks \\
\hline \multicolumn{4}{|l|}{ Biomethane } \\
\hline Paturska et al. & [7] & 46 & Consideration of anaerobic digestion only \\
\hline Zappa et al. & [95] & 49 & Consideration of anaerobic digestion only \\
\hline van Melle et al. & [12] & 52 & $\begin{array}{l}\text { Average cost reflecting both anaerobic digestion and } \\
\text { thermal gasification }\end{array}$ \\
\hline European Commission & [83] & $61-68$ & Average cost; considering anaerobic digestion only \\
\hline Budzianowski et al & [11] & 70 & Consideration of anaerobic digestion only \\
\hline Papp et al. & {$[8]$} & $62-94$ & $\begin{array}{l}\text { Cost range reflects different combinations of plant size, } \\
\text { plant technology, and feedstock }\end{array}$ \\
\hline Thrän et al. & [9] & $69-94$ & $\begin{array}{l}\text { Consideration of anaerobic digestion only; cost range } \\
\text { reflects different combinations of plant size, plant } \\
\text { technology, and feedstock }\end{array}$ \\
\hline $\begin{array}{l}\text { International Renewable Energy Agency } \\
\text { (IRENA) }\end{array}$ & [110] & 84 & $\begin{array}{l}\text { Average cost for different residues feedstocks in a high- } \\
\text { cost environment }\end{array}$ \\
\hline \multicolumn{4}{|l|}{ Renewable hydrogen } \\
\hline van Melle et al. & [12] & 52 & Low-cost excess electricity only \\
\hline Perner et al. & [60] & $50-75$ & $\begin{array}{l}\text { Based on strong economies of scale due to significant } \\
\text { increase of global electrolyser capacity; applicable for } \\
\text { both production based on low-cost excess electricity in } \\
\text { Europe and maximized production in commercially } \\
\text { attractive regions outside the EU (for the latter incl. } \\
\text { transport) }\end{array}$ \\
\hline Van Wijk, A. & [52] & 63 & $\begin{array}{l}\text { Based on baseload production using mainly off-shore } \\
\text { wind power }\end{array}$ \\
\hline \multicolumn{4}{|l|}{ Synthetic renewable methane } \\
\hline Perner et al. & [60] & 100-150 & $\begin{array}{l}\text { Based on strong economies of scale due to significant } \\
\text { increase of global electrolyser capacity; applicable for } \\
\text { both production based on low-cost excess electricity } \\
\text { in Europe and maximized production in commercially } \\
\text { attractive regions outside the EU (for the latter incl. transport) }\end{array}$ \\
\hline
\end{tabular}

and timelines, both the relative comparability and the general validity of these estimates are limited. However, the overview provided in Table 5 enables an overall estimate of the competitiveness of renewable gases as compared to natural gas. With production costs for sustainable biomethane expected at a level of 46-94 $€ / \mathrm{MWh}$, production cost for renewable hydrogen at a level of $52-75 € / \mathrm{MWh}$, and the corresponding costs for synthetic renewable methane at a level of 100-150 $€ / \mathrm{MWh}$, they all lie substantially above the currently observed average European wholesale price for natural gas (around $20 € / \mathrm{MWh}$ ) [98]. If the gas price stays at this level and as long as there is no comprehensive carbon pricing regime, rational economic decisions to invest in major additional renewable gas production can only be expected if backed by effective support to compensate for the premium over the natural gas wholesale price $[9,99,100]$. We empirically examined one such support scheme (see "Enabling factors for gas sector contributions to a future EU energy system" section for description and "Enabling factors" section for discussion). For further information regarding renewables support schemes in general, we refer the interested reader to the paper of Kitzing et al, which provides a comprehensive overview of the different policies applied in Europe [101].

The necessity to support scaling-up of renewable gas production with public interventions is one of the major conclusions of the reviewed studies ("Potential contributions of the gas sector to a future EU energy system based on the reviewed literature" section for details). In addition, some of the studies argue that, considering the massive transformation required to build a climateneutral energy system, the natural gas price does not appear to be a proper benchmark for renewable gas production costs in a long-term context. Production costs for renewable gas should rather be compared with renewable alternatives. In addition, for a full picture from a societal perspective, they should be considered in combination with resulting additional costs along the entire energy supply chain $[12,15,44]$. As outlined above, renewable gases can largely be supplied through existing network and storage infrastructure. Massive expansion will be required in renewable gas production, and this 
hinges on sufficient financial support [10,99]. This is a situation we observe not only in renewable gas but for the broad majority of renewable energy generation technologies and approaches $[13,78]$.

The Council of European Energy Regulators recently assessed the level of public support for promoting renewable electricity across Europe [78]. Their results reflect the wide range of generation technologies, support schemes, and levels of technical development over more than a decade of public renewable electricity support in the form of feed-in tariffs, feed-in premiums, etc. The aggregated findings of the report are particularly pertinent for assessing the economic competitiveness of renewable gas production. Figure 4 illustrates the range of support required for renewable gas and compares it to actual support levels for electricity as identified by the Council of European Energy Regulators [78].

Figure 4 also illustrates that renewable electricity is receiving substantial support (see green box). The level of this support strongly differs between technologies, both for average and $\min / \max$ values. If aggregated, the weighted average support level for renewable electricity produced in Europe was $96.29 € / \mathrm{MWh}$ in 2017 [78]. While there are new installations that receive no public support at all, the reported average support level just for new installations put in operation in 2016 is, at 116.56 $€ / M W h$, even higher than the average across all installations in operation [78]. Based on the renewable gas production cost estimates (see Table 5) and the recently observed average European wholesale price for natural gas of around $20 € / \mathrm{MWh}$ [98], support for renewable gas production (see blue box) across the different types of renewable gas needs to be between $26 € / M W h$ and $130 € / M W h$. This indicates that the support granted to most renewable electricity production technologies would be sufficient for renewable gas also.

In addition, renewable electricity receives different forms of indirect support that greatly differ between Member States. It ranges from reduced charges for initial grid connection or different self-consumption allowances to priority dispatch of renewable electricity [78]. Renewable electricity in the amount of 9651 GWh had to be curtailed for redispatch reasons in 2017, and renewable electricity producers had to be compensated for this by compensation payments totaling more than 850 million $€[78]$.

\section{Societal implications}

Curtailment is an example that serves to illustrate why transforming the energy system is not limited to energy production but requires a holistic approach that includes production, network, storage, and end-use appliances. Overall, the interplay of various energy vectors and their infrastructure should be optimized in order to secure energy supply while limiting the increase of total energy system costs $[12,15]$. We consider this to be critical for the transformation of the energy system. While society increasingly acknowledges the need for action to mitigate the negative impact of climate change, public choice-based research postulates that individuals pay more attention to their specific economic short-term development (disposable income, employment, etc.) than to mitigating climate change [102]. Against this background, we use the determined support levels for renewable gas to derive the indicative additional annual cost (AAC) for gas end-users to enable substituting natural gas by renewable gases. The AAC is calculated as follows (see Table 6 for details about the variables used):

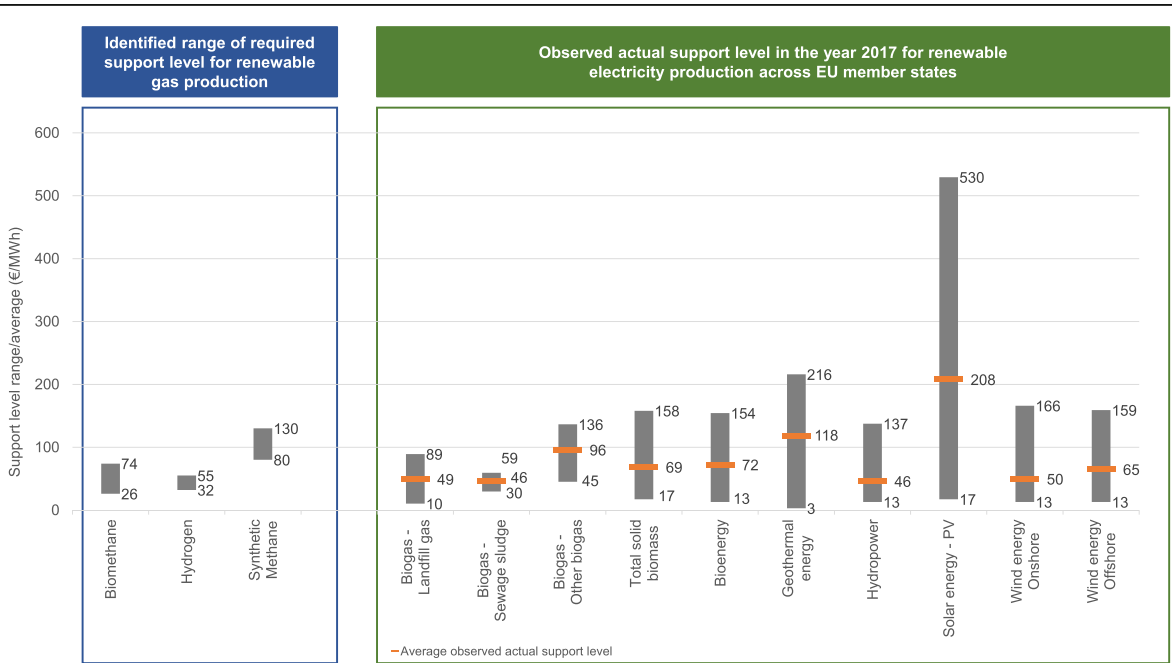

Fig. 4 Estimated support levels for renewable gas and actual support levels for renewable electricity across Europe (based on Table 5 and $[78,98])$ 
Table 6 Variables for the calculation of the indicative additional annual cost (AAC)

\begin{tabular}{llll}
\hline Variable & Meaning & Source & Remark \\
\hline SUL & Support level for renewable gas production & Table 5; [98] & $\begin{array}{l}\text { Varies from } 30 \text { to 130 EUR/MWh, reflecting the broad range of production } \\
\text { cost estimates for different technologies }\end{array}$ \\
TGD & Total gas demand & {$[88]$} & $\begin{array}{l}\text { Projected demand for } 2030 \text { (2803 TWh) } \\
\text { S }\end{array}$ \\
$\begin{array}{l}\text { Share of total gas demand to be covered } \\
\text { by renewable gas }\end{array}$ & - & $\begin{array}{l}\text { Varied from } 10 \text { to 100\%, illustrating the impact of different penetration } \\
\text { targets }\end{array}$ \\
TN & $\begin{array}{l}\text { Total number of end-users connected to } \\
\text { the gas grid }\end{array}$ & {$[52]$} & $\begin{array}{l}\text { Assumption that costs would be equally shared among all } 118 \text { million } \\
\text { end-users connected to the gas grid (irrespective of type and size) }\end{array}$ \\
\hline
\end{tabular}

$$
\mathrm{AAC}=\frac{\mathrm{SUL} \times \mathrm{TGD} \times \mathrm{S}}{\mathrm{TN}}
$$

Figure 5 provides an overview of the calculated AAC for different penetration levels of renewable gas substituting natural gas (based on the officially projected demand for 2030, 2803 TWh [88]) and different support levels for renewable gas production. If the costs of the support scheme are equally distributed among all endusers that are connected to the gas grid, the AAC per end-user ranges from approximately $€ 70$ (support level $30 € / \mathrm{MWh} ; 10 \%$ share) to $€ 3100$ (support level 130 $€ / \mathrm{MWh} ; 100 \%$ share). Considering that the vast majority of end-users in Europe are households that pay approximately $€ 1000$ for the $15,000 \mathrm{kWh}$ of gas they consume on average [103, 104], the higher end of the AAC range is out of the question. By way of comparison, if all European gas end-users were to switch their gas supplier (which most have not ever done so far), they could realize an annual savings potential of up to $€ 400$ each [103]. This savings potential matches the AAC for a $50 \%$ penetration level of renewable gas that is produced at the lowest production cost reported. Any higher AAC could be expected to impact households' financial situation, possibly affecting public acceptance of the transformation of the energy system in general [70].
In such a situation, utility-maximizing politicians might face opposition for environmental and energy policies with the level of ambition required to indeed reach their GHGE reduction commitments [102]. For that very reason and in order to facilitate the transformation of the energy system in line with these commitments, it appears crucial to provide an energy policy framework that enables the most cost-efficient future energy system design.

Against this background and according to the reviewed studies dealing with potential gas sector contributions (see "Potential contributions of the gas sector to a future EU energy system based on the reviewed literature" section for details), the major advantages of renewable gas lie in the reduced investment needs along the supply chain. Existing gas storage can address the strongly increasing need for seasonal balancing, existing gas networks can reduce the magnitude of electricity network expansion that will be necessary, and supplying renewable gas to end-users makes major adaptations on the end-user side unnecessary. One of the studies we reviewed quantifies the resulting societal cost benefits at more than $€ 100$ billion per year at EU level [12]. Other studies with national scope arrive at comparable results $[15,63,72]$. Even though expanding renewable gas production will require substantial public support, this is equally true for most renewable electricity production

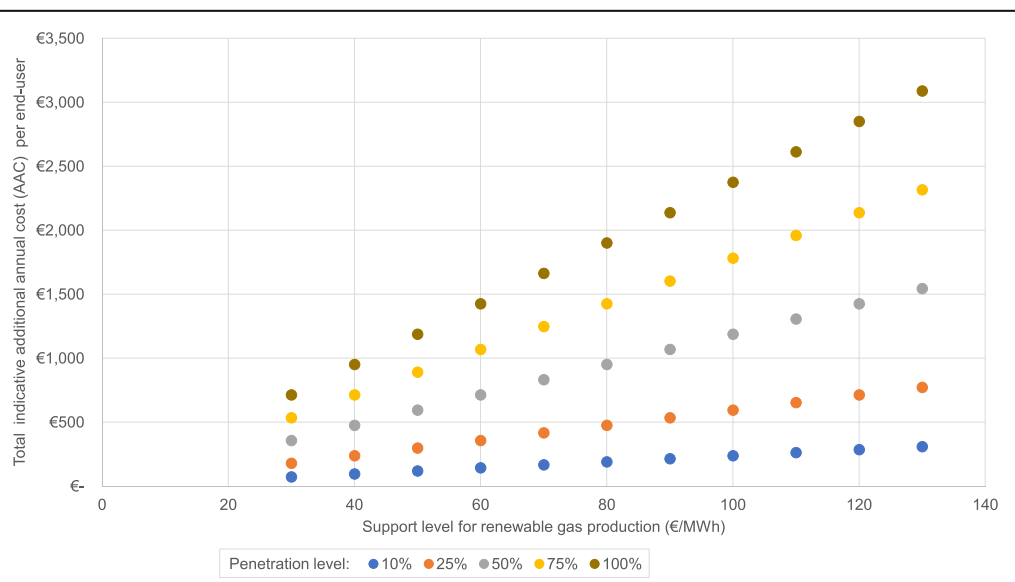

Fig. 5 AAC per gas end-user based on different support levels and penetration paths for renewable gas (calculations based on Table 5 and [31, 88, 98]) 
$[78,100]$. Indeed, public support for renewable electricity production has led to doubling its share in total electricity delivered to end-users over the last 10 years to reach $30 \%$ in 2016 [105]. Based on that, the support schemes can be considered to have been effective [106]. With regards to efficiency, the weighted average support level for renewable electricity produced across Europe in 2017 was $96.69 € / M W h$. Given that in 2017, supported installations generated about $603 \mathrm{TWh}$ renewable electricity, the total public support volume in this specific year was around 58 billion $€$. For the period from 2005 to 2030, the total public support volume for renewable electricity production is estimated to be 900 billion $€[100]$.

At the moment, the situation of renewable gases is literally the opposite. Public support for renewable gas injected into the gas grid to be supplied to end-users in gaseous form exists in some Member States but is rather insignificant at a European level $[9,83]$. The same holds true for the share of renewable gas in total gas consumption in general. Therefore, we complement the discussion of societal implications with a what-if analysis, looking at what would be the effects if the public support provided to renewable electricity production in 2017 were available for renewable gas also.

Figure 6 illustrates that an annual support volume of 58 billion $€$ (as granted to renewable electricity in 2017) would enable a renewable gas penetration of $70 \%$ in 2030 if that gas is produced at the lowest production cost identified (see Table 5). With average production costs, i.e., an average support level of $80 € / \mathrm{MWh}$, penetration would be slightly more than $25 \%$ and account for approximately $700 \mathrm{TWh}$ of renewable gas production. Compared to the $603 \mathrm{TWh}$ of supported renewable electricity that were produced in 2017 [78], supported renewable gas would mean close to 100 TWh of renewable energy more delivered to end-users, with similar societal costs. This is not meant to express a preference for renewable gas over renewable electricity; the two energy vectors have strengths in different end-use segments and conditions. Public support schemes for each form of renewable energy should reflect this and, in particular, should incorporate the effects along the entire supply chain, focusing on optimizing total energy system costs.

Beyond these potential cost benefits for society, renewable gases might facilitate public acceptance for this major change and thus contribute to speeding up the transition process toward a climate-neutral energy system as compared to an energy system design without renewable gases. While most of the reviewed studies were prepared or commissioned by organizations close to the gas sector, the study by the industry association of the European electricity industry comes to very similar conclusions, including a substantial level of renewable gas in the energy supply mix [34]. Additionally, similar views have been expressed by the European Commission and the Council of European Energy Regulators. These organizations can be expected to take a neutral stance and aim to optimize the energy supply chain as a whole and across the different energy sources and vectors. Nonetheless, further research could pay special attention to additional views of further energy sector stakeholders.

\section{Enabling factors}

In addition to the need for a support scheme to improve the business case of renewable gas production for operators and investors $[9,99,100]$, our empirical work with focus on the Austrian case delivered a somewhat broader picture of factors for enabling gas sector contributions in an efficient and sustainable way. While these different elements might not be fully applicable or relevant in other EU member states and specific national characteristics could lead to different conclusions, we

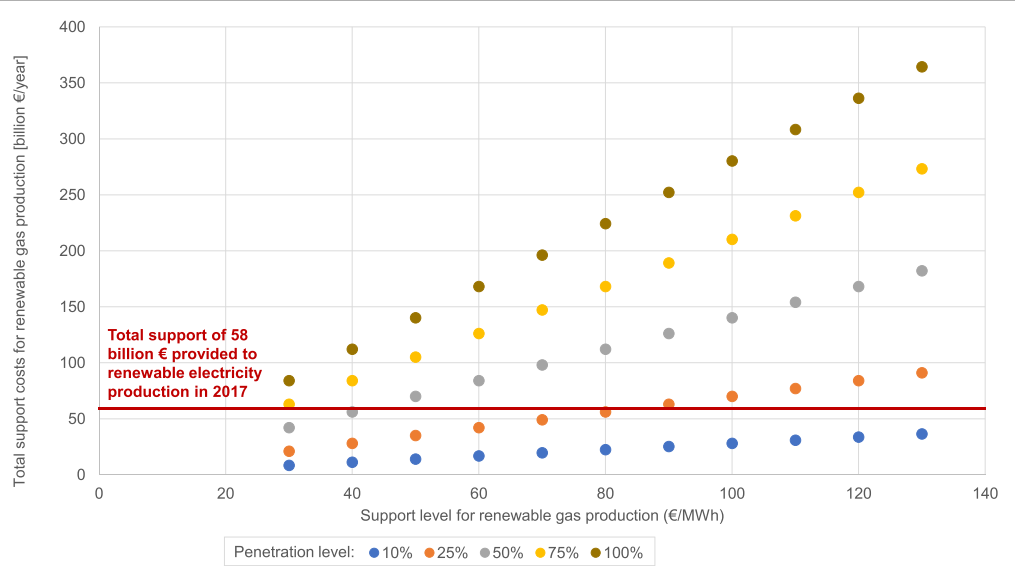

Fig. 6 Comparison of potential support costs for renewable gas with actual support costs for renewable electricity (calculations based on Table 5 and $[78,88,98])$ 
believe the central observations addressed below have general validity.

Firstly, we identified a substantial difference in the support levels that are required for the different types of renewable gas. According to our empirical results, support levels should take into account the different technology readiness levels of renewable gas production technologies. This is also supported by previous research, which came to the conclusion that technologyspecific RES support can create substantial economic benefits $[107,108]$.

Secondly, even though renewable gas support schemes differ across Europe and generally fall behind support for renewable electricity $[7,9,83]$, a support scheme design with feed-in tariffs or premiums whose amount is determined via auctions is broadly in line with recent discussions among scholars and policy makers. Indeed, more and more schemes use market-based instruments, accounting for the fact that auctions allocate scarce funds more effectively [27, 78, 79]. With regards to the support period, research suggests that it should be longer than 10 years since it significantly impacts the necessary relative support level and enhances the attractiveness of renewable gas projects for investors [10]. The proposed funding mechanism, i.e., a non-tax support levy payable by gas end-users, corresponds to the most common form of public support currently in place [78]. Considering that the number of gas-end users is only about half the number of electricity end-users [30, 31], but that both energy vectors will need substantial public support to turn renewable, the financial question appears to be particularly sensitive for gas. When deciding how to finance a support scheme, the potential direct social impact in the residential sector [69] and the influence of additional energy charges on the competitive cost position of the industry must be considered [66] Otherwise, gas end-users might be forced to switch fuels, which bears the risk of creating issues and costs further up the supply chain. This can be expected to hold true for network costs in general and underlines the need for a sufficiently high utilization rate of the gas infrastructure across network levels as a prerequisite for supplying renewable gas to end-users in a cost effective way.

Thirdly, optimizing total energy system costs across renewable energy vectors requires a technology-neutral approach. This has implications for several policy areas. For instance, the European Commission, in its longterm vision toward achieving a climate-neutral economy, attributes a key role to renewable gas in the buildings sector [83], but the true potential of renewable gas can only unfold if building regulation ensures fair treatment on a par with renewable electricity. Even though renewable electricity-based heat pumps are highly efficient if combined with the right heating system characteristics and energy efficiency standards, renewable gas could be a cost-efficient and quick solution for a large part of the building stock where electrification is facing feasibility and affordability limits $[12,15,44,68]$.

\section{Conclusions}

Europe's gas sector currently services around 118 million end-users and covers between 20 and $25 \%$ of overall European final energy demand. At the same time, EU energy policy makers have formulated the vision of moving into climate-neutral energy supply by 2050 , thus saving $75 \%$ of total GHGE. Clearly, the gas sector cannot continue with its "business as usual" and its focus on natural gas, but there is the growing realization that a fundamentally transformed gas sector could play a major role in the future. To further home in on this role, we have applied an integrative approach and discussed how, to which extent and based on which prerequisites the gas sector could indeed contribute to an increasingly climate-neutral future EU energy system. We consider the following aspects most important:

- We found convincing arguments that the role of gas need not be limited to balancing volatile RES but that it could also enable climate-neutral energy enduse through the utilization of existing infrastructure in the public domain and on end-user side in a relatively cost-efficient way.

- While the technologies for producing biomethane, synthetic renewable methane, and hydrogen exist, actual production volumes are negligible. This need not be the case. According to our review of estimates, there is technical potential to substitute between 11 and $55 \%$ of projected total EU gas demand in 2050 with biomethane alone; this corresponds to between 24 and $100 \%$ of projected gas consumption by residential end-users. Further work will be required to verify the applicability of such findings for specific national cases.

- The purely technical potential of synthetic renewable methane or hydrogen is nearly inexhaustible, but its effective potential strongly depends on energy system design. Substituting large shares of natural gas with renewable gas seems rather unrealistic if we limit power-to-gas to excess RES electricity, but it appears possible if we factor in imports of renewable gas from low-cost production regions.

- Production cost estimates are in a range of 46-94 $€ / \mathrm{MWh}$ for biomethane, $52-75 € / \mathrm{MWh}$ for renewable hydrogen, and 100-150 $€ / \mathrm{MWh}$ for renewable synthetic methane. Even though such estimates need to be considered with caution and 
actual costs differ from case to case, it is evident that production costs are substantially higher than the natural gas market price. Consequently, private investment in renewable gas production can only be expected to reach the levels necessary for a system transformation if backed by an enabling energy policy framework including an effective public support scheme.

- There are strong public support schemes for renewable electricity across the EU. The EUweighted average support stood at $96.29 € / \mathrm{MWh}$ in 2017; for new installations, the reported average was even higher at $116.56 € / \mathrm{MWh}$. We have calculated that renewable gas would require support levels between 26 and $130 € / \mathrm{MWh}$, depending on the technology used. This means that the observed support levels for renewable electricity would generally be sufficient for renewable gas also.

- Such support schemes are usually financed through levies on end-users. The additional costs to endusers that would arise from the support levels necessary and high renewable gas penetration rates might run into public acceptance risks. We argue that a $50 \%$ renewable gas penetration rate at low production costs could be acceptable for end-users without having to compensate in other areas. This would enable about $1400 \mathrm{TWh} / \mathrm{a}$ of renewable gas (as compared to a total renewable electricity production of around 600 TWh in 2017, with a higher absolute level of public support).

- To ensure an energy system transition that allows for achieving climate targets, policy makers need to aim for an optimized interplay of various energy vectors and their infrastructure along the entire supply chain. This is important to maintain safe and secure energy supplies while limiting the increase of total energy system costs. The societal cost benefits at EU level related to renewable gases, continued use of existing gas assets, reduced electricity network expansion needs, and redundant adaptations on the end-user side could be beyond $100 €$ billion per year.

- To realize such benefits, a level playing field for renewable gas and electricity should be established across policy areas. Public support for renewable gas production should reflect the development stages of different production pathways. Support schemes should be market-based and provide sufficiently reliable and attractive investment conditions.

- Allocating support costs to end-users via levies needs to be approached with caution. Gas end-users should not be pushed into fuel switching if this creates issues further up the supply chain, thereby increasing total energy system costs in the long run.
Together with the notion of public acceptance for energy transition in general, this represents an important avenue for further research.

\section{Endnotes}

${ }^{1}$ Comparing these 118 million end-users connected to the European gas grid with 260 million end-users [30] of electricity (which we consider a necessity for any household or business) shows that across Europe approx. 45\% of all European end-users are connected to the gas grid.

${ }^{2}$ The Austrian legal framework stipulates that social partners such as the Chamber of Labour, the Chamber of Commerce, the Chamber of Agriculture and the Federation of Austrian Industries have party status in proceedings of the Austrian regulatory authority for electricity and gas [32]. Therefore, representatives of these institutions were involved in the discussion process to bring in their respective views already at an early conceptual stage.

${ }^{3}$ The EU Energy Roadmap articulates the expectation of a share of electricity in final energy consumption that increases from $22 \%$ today to $35-40 \%$ in 2050 [21]. The European association of the electricity industry even expects a level of direct electrification of 38-60\% [34]

${ }^{4}$ While $75 \%$ of the existing building stock is energy inefficient, only $0.4-1.2 \%$ of buildings across EU member states are renovated each year [68].

${ }^{5}$ In case of on-site use of raw biogas solely for electricity production (typically the case if there is insufficient local heat demand, which can easily be the case in rural areas), only up to $35 \%$ of the gaseous energy are utilized. If the biogas is upgraded to biomethane and injected into the gas grid various end-uses with efficiencies up to 90\% and more (e.g., domestic gas-fired heating system) are possible $[7,84]$.

\section{Abbreviations \\ $€$ : Euro; $\mathrm{AAC}$ : Average annual cost; $\mathrm{CO}_{2}$ : Carbon dioxide; EU: European Union; GHGE: Greenhouse gas emissions; km: Kilometers; MWH: Megawatt hour; RES: Renewable energy sources; SMEs: Small and medium-sized enterprises; TWh: Terawatt hour}

\section{Acknowledgements \\ The authors would like to thank the Austrian Association of Gas- and District Heating Companies for their consent to use empirical focus group data for this research. Moreover, the valuable and detailed comments on earlier drafts of this paper provided by Dorothea Greiling and Friedrich Schneider as well as three anonymous reviewers are highly appreciated.}

\section{Funding}

No funding of research.

\section{Availability of data and materials}

All data which support our conclusions are presented in this paper. The original transcripts of focus group sessions are not published to protect the privacy of the discussion participants.

\section{Authors' contributions}

Both authors designed the objectives and methods of this paper and contributed to the conclusions. CL carried out the review, analyzed the 
empirical data, and discussed the results while HS designed and conducted the underlying empirical study. Both authors read and approved the final manuscript.

\section{Ethics approval and consent to participate} Not applicable.

\section{Consent for publication}

Not applicable.

\section{Competing interests}

The authors declare that they have no competing interests.

\section{Publisher's Note}

Springer Nature remains neutral with regard to jurisdictional claims in published maps and institutional affiliations.

Received: 12 October 2018 Accepted: 3 June 2019

Published online: 13 June 2019

\section{References}

1. Eurostat (2018) Final energy consumption by product. https://ec.europa.eu/ eurostat/tgm/table.do?tab=table\&init=1\&language=en\&pcode= ten00123\&plugin=1. Accessed 14 Mar 2019

2. European Network of Transmission System Operators for Gas (2015) Securing Europe's energy future: implementing the internal market for gas. Annual Report 2015. https://www.entsog.eu/public/uploads/files/ publications/AWP\%20\&\%20Annual\%20Report/2016/entsog_ar2015_160708_ hires.pdf. Accessed 14 Mar 2019

3. Wall DM, McDonagh S, Murphy JD (2017) Cascading biomethane energy systems for sustainable green gas production in a circular economy. Bioresour Technol 243:1207-1215. https://doi.org/10.1016/j.biortech.2017.07. 115

4. Götz M, Lefebvre J, Mörs F et al (2016) Renewable power-to-gas: a technological and economic review. Renew Energ 85:1371-1390. https:// doi.org/10.1016/j.renene.2015.07.066

5. Scarlat N, Dallemand J-F, Fahl F (2018) Biogas: developments and perspectives in Europe. Renew Energ 129:457-472. https://doi.org/10.1016/j. renene.2018.03.006

6. Baldino C, Pavlenko N, Searle S et al. (2018) The potential for low-carbon renewable methane in heating, power, and transport in the European Union: Working Paper 2017-26. https://www.theicct.org/sites/default/files/ publications/Renewable_Gas_EU-28_20181016.pdf. Accessed 14 Mar 2019

7. Paturska A, Repele M, Bazbauers G (2015) Economic assessment of biomethane supply system based on natural gas infrastructure. Energy Procedia 72:71-78. https://doi.org/10.1016/j.egypro.2015.06.011

8. Papp EJ et al. (2017) Riesiges Potential an grünem Gas. http://www. energieinstitut-linz.at/v2/wp-content/uploads/2017/09/FORUM_GAS WASSER_W\%C3\%84RME_2017_04.pdf. Accessed 14 Mar 2019

9. Thrän D, Billig E, Persson T et al (2014) Biomethane - status and factors affecting market development and trade: IEA task 40 and task 37 joint study. IEA Bioenergy, Paris

10. Repele M, Udrene L, Bazbauers G (2017) Support mechanisms for biomethane production and supply. Energy Procedia 113:304-310. https:// doi.org/10.1016/j.egypro.2017.04.070

11. Budzianowski WM, Budzianowska DA (2015) Economic analysis of biomethane and bioelectricity generation from biogas using different support schemes and plant configurations. Energy 88:658-666. https://doi. org/10.1016/j.energy.2015.05.104

12. van Melle T, Peters D, Cherkasky J et al. (2018) Gas for climate: how gas can help to achieve the Paris agreement target in an affordable way. https:// www.gasforclimate2050.eu/files/files/Ecofys_Gas_for_Climate_Feb2018.pdf. Accessed 14 Mar 2019

13. Bouré $Q$, Cherrey M, Coupé $F$ et al. (2018) A 100\% renewable gas mix in 2050?: study summary. https://www.ademe.fr/sites/default/files/assets/ documents/renewable-gas-mix-2050-010521.pdf. Accessed 14 Mar 2019

14. Hecking $H$, Hintermayer M, Lencz D et al. (2017) Energiemarkt 2030 und 2050 - Der Beitrag von Gas- und Wärmeinfrastruktur zu einer effizienten CO2-Minderung. http://www.ewi.research-scenarios.de/cms/ wp-content/uploads/2017/11/ewi_ERS_Energiemarkt_2030_2050.pdf. Accessed 14 Mar 2019
15. Bothe D. et al. (2017) Der Wert der Gasinfrastruktur für die Energiewende in Deutschland: Eine modellbasierte Analyse. https://www.fnb-gas.de/files/fnb_ gas_wert_von_gasinfrastruktur-endbericht.pdf. Accessed 14 Mar 2019

16. Klein S, Klein SW, Steinert T et al. (2017) Erneuerbare Gase - Ein Systemupdate der Energiewende. http://erdgasspeicher.de/files/20171212_ studie_erneuerbare_gase.pdf. Accessed 14 Mar 2019

17. European Commission (2011) A roadmap for moving to a competitive low carbon economy in 2050. http://eur-lex.europa.eu/legal-content/EN/TXT/ PDF/?uri=CELEX:52011DC0112\&from=EN. Accessed 14 Mar 2019

18. Rockström J, Gaffney O, Rogelj J et al (2017) A roadmap for rapid decarbonization. Science 355(6331):1269-1271. https://doi.org/10.1126/ science.aah3443

19. United Nations Framework Convention on Climate Change (2016) Report of the conference of the parties on its twenty-first, this session, held in Paris from 30 November to 13 December 2015. https://unfccc.int/sites/default/ files/resource/docs/2015/cop21/eng/10a01.pdf. Accessed 14 Mar 2019

20. European Commission (2018) A clean planet for all: a European strategic long-term vision for a prosperous, modern, competitive and climate neutral economy. https://ec.europa.eu/clima/sites/clima/files/docs/pages/com_ 2018_733_en.pdf. Accessed 14 Mar 2019

21. European Commission (2011) Energy roadmap 2050. http://eur-lex.europa. eu/legal-content/EN/TXT/PDF/?uri=CELEX:52011DC0885\&from=EN. Accessed 14 Mar 2019

22. Council of European Energy Regulators (2018) Study on the future role of gas from a regulatory perspective. https://www.ceer.eu/documents/ 104400/-/-/6a6c72de-225a-b350-e30a-dd12bdf22378. Accessed 14 Mar 2019

23. European Commission (2014) European Energy Security Strategy: SWD(2014) 330 final. http://eur-lex.europa.eu/legal-content/EN/TXT/PDF/?uri=CELEX: 52014DC0330\&from=EN. Accessed 14 Mar 2019

24. Stram BN (2016) Key challenges to expanding renewable energy. Energy Policy 96:728-734. https://doi.org/10.1016/j.enpol.2016.05.034

25. European Parliament and the Council of the European Union (2012) Directive 2012/27/EU of the European Parliament and of the council of 25 October 2012 on energy efficiency, amending directives 2009/125/EC and 2010/30/EU and repealing directives 2004/8/EC and 2006/32/EC. Off J Eur Union L 315:1-56

26. European Parliament and the Council of the European Union (2018) Directive (EU) 2018/844 of the European Parliament and of the council amending directive 2010/31/EU on the energy performance of buildings and directive 2012/27/EU on energy efficiency. Off J Eur Union L 156:75-91

27. European Parliament and the Council of the European Union (2018) Directive (EU) 2018/2001 on the promotion of the use of energy from renewable sources (recast). Off J Eur Union L 328:82-209

28. Bundesverband der Energie- und Wasserwirtschaft (2040) Deutsche Gesellschaft für Internationale Zusammenarbeit, PricewaterhouseCoopers (2016) Delphi Energy Future 2040: Delphi-Studie zur Zukunft der Energiesysteme in Deutschland. In: Europa und in der Welt im Jahr https:// www.pwc.de/de/energiewirtschaft/assets/delphi_energy_future_2040.pdf. Accessed 14 Mar 2019

29. European Commission (2017) Conclusions of the 30th meeting of the European regulatory gas forum (Madrid Forum). https:/ec.europa.eu/energy/sites/ener/files/ documents/30th_mf_conclusions_final.pdf. Accessed 14 Mar 2019

30. Eurelectric (2013) Power distribution in Europe: Facts \& Figures. https:// www3.eurelectric.org/media/113155/dso_report-web_final-2013-030-076401-e.pdf. Accessed 14 Mar 2019

31. GEODE Working Group Gas (2014) The future role of gas distribution networks: delivering gas to consumers. http://www.geode-eu.org/uploads/ Gas\%20Report.pdf. Accessed 14 Mar 2019

32. Austrian Parliament (2019) Bundesgesetz über die Regulierungsbehörde in der Elektrizitäts- und Erdgaswirtschaft (Energie-Control-Gesetz - E-ControlG). Federal Law Gazette of the Republic of Austria

33. Bundesministerium für Nachhaltigkeit und Tourismus sowie Bundesministerium für Verkehr, Innovation und Technologie (2018) \#mission2030: Die österreichische Klima- und Energiestrategie. https:// mission2030.info/wp-content/uploads/2018/06/Klima-Energiestrategie.pdf. Accessed 14 Mar 2019

34. eurelectric (2018) Decarbonization pathways. https://cdn.eurelectric.org/ media/3457/decarbonisation-pathways-h-5A25D8D1.pdf. Accessed 14 Mar 2019

35. Eurostat (2018) Supply, transformation and consumption of electricity_annual data: nrg_105a. https://ec.europa.eu/eurostat/data/ 
database?p_p_id=NavTreeportletprod_WAR_NavTreeportletprod_ INSTANCE_nPqeVbPXRmWQ\&p_p_lifecycle=0\&p_p_state=pop_up\&p_p_ mode=view\&p_p_col_id =column-2\&p_p_col_pos $=1 \&$ p_p_col_count $=2 \&$ _ NavTreeportletprod_WAR_NavTreeportletprod_INSTANCE_

nPqeVbPXRmWQ_nodelnfoService $=$ true\&nodeld $=246156$. Accessed $14 \mathrm{Mar}$ 2019

36. Gimeno-Gutiérrez M, Lacal-Arántegui R (2013) Assessment of the European potential for pumped hydropower energy storage: a GIS-based assessment of pumped hydropower storage potential. Publications Office of the European Union, Luxembourg

37. Gas Infrastructure Europe (2018) GIE storage database. https:/www.gie.eu/ maps_data/downloads/2018/Storage_DB_Dec2018.xlsx. Accessed 14 Mar 2019

38. Jülch V (2016) Comparison of electricity storage options using levelized cost of storage (LCOS) method. Appl Energy 183:1594-1606. https://doi.org/10. 1016/j.apenergy.2016.08.165

39. Gallo AB, Simões-Moreira JR, Costa HKM et al (2016) Energy storage in the energy transition context: a technology review. Renew Sust Energ Rev 65: 800-822. https://doi.org/10.1016/j.rser.2016.07.028

40. Lewandowska-Bernat A, Desideri U (2018) Opportunities of power-to-gas technology in different energy systems architectures. Appl Energy 228:5767. https://doi.org/10.1016/j.apenergy.2018.06.001

41. Council of European Energy Regulators (2018) CEER benchmarking report 6 . 1 on the continuity of electricity and gas supply: data update 2015/2016. https://www.ceer.eu/documents/104400/-/-/963153e6-2f42-78eb-22a406f1552dd34c. Accessed 14 Mar 2019

42. Battaglini A, Komendantova N, Brtnik P et al (2012) Perception of barriers for expansion of electricity grids in the European Union. Energy Policy 47:254259. https://doi.org/10.1016/j.enpol.2012.04.065

43. Becker S, Rodriguez RA, Andresen GB et al (2014) Transmission grid extensions during the build-up of a fully renewable pan-European electricity supply. Energy 64:404-418. https://doi.org/10.1016/j.energy.2013.10.010

44. Nymoen|strategieberatung (2017) Green gas potential in ONTRAS network area. https://vng.de/sites/default/files/ontras_nymoen_strategieberatung_ ptg-_potenziale_im_ontras-_netzgebiet.pdf. Accessed 14 Mar 2019

45. Schaaf T, Grünig J, Schuster MR et al (2014) Methanation of CO2-storage of renewable energy in a gas distribution system. Energ Sustain Soc 4(1): 342. https://doi.org/10.1186/s13705-014-0029-1

46. Bagi Z, Ács N, Böjti T et al (2017) Biomethane: the energy storage, platform chemical and greenhouse gas mitigation target. Anaerobe 46:13-22. https:// doi.org/10.1016/j.anaerobe.2017.03.001

47. Mathiasson A (2017) Perspectives for biogas within the EU: future of biogas Europe 2017. https:/www.biogas2020.se/wp-content/uploads/2017/11/nr-1eba-perspectives.pdf. Accessed 01 Feb 2019

48. European Commission (2017) Action plan on alternative fuels infrastructure under article 10(6) of Directive 2014/94/EU. https://www.actuenvironnement.com/media/pdf/news-30015-alternative-fuels-ue.pdf. Accessed 14 Mar 2019

49. Hennig C, Brosowski A, Majer S (2016) Sustainable feedstock potential-a limitation for the bio-based economy? J Clean Prod 123:200-202. https:// doi.org/10.1016/j.jclepro.2015.06.130

50. European Commission (2014) Towards a circular economy: a zero waste programme for Europe. https://eur-lex.europa.eu/resource.html?uri=cellar: aa88c66d-4553-11 e4-a0cb-01 aa75ed71a1.0022.03/DOC_1\&format=PDF. Accessed 14 Mar 2019

51. Ball M, Weeda M (2015) The hydrogen economy - vision or reality? Int J Hydrog Energy 40(25):7903-7919. https://doi.org/10.1016/j.jijhydene. 2015.04.032

52. van Wijk A (2017) The green hydrogen economy in the northern Netherlands. http://profadvanwijk.com/wp-content/uploads/2017/04/NIB-BPEN-DEF-webversie.pdf. Accessed 14 Mar 2019

53. Abdalla AM, Hossain S, Nisfindy OB et al (2018) Hydrogen production, storage, transportation and key challenges with applications: a review. Energy Convers Manag 165:602-627. https://doi.org/10.1016/j.enconman. 2018.03.088

54. Sadler D, Cargill A, Crowther M et al. (2016) H21: Leeds City Gate. https:// www.northerngasnetworks.co.uk/wp-content/uploads/2017/04/H21-ReportInteractive-PDF-July-2016.compressed.pdf. Accessed 14 Mar 2019

55. Holmen A, Olsvik O, Rokstad OA (1995) Pyrolysis of natural gas: chemistry and process concepts. Fuel Process Technol 42(2-3):249-267. https://doi. org/10.1016/0378-3820(94)00109-7
56. Gazprom Export (2018) BLUE FUEL: Gazprom Export Global Newsletter. http://www.gazpromexport.ru/files/BLUE_FUEL_48326.pdf. Accessed 14 Mar 2019

57. Mansilla C, Avril S, Imbach J et al (2012) CO2-free hydrogen as a substitute to fossil fuels: what are the targets? Prospective assessment of the hydrogen market attractiveness. Int J Hydrog Energy 37(12):9451-9458. https://doi.org/10.1016/j.jijydene.2012.03.149

58. Reiter G, Lindorfer J (2015) Evaluating CO2 sources for power-to-gas applications-a case study for Austria. J CO2 Util 10:40-49. https://doi.org/ 10.1016/j.jcou.2015.03.003

59. Keith DW, Holmes G, St. Angelo D et al (2018) A process for capturing CO2 from the atmosphere. Joule. https://doi.org/10.1016/j.joule.2018.05.006

60. Perner J, Unteutsch M, Lövenich A (2018) The future cost of electricitybased synthetic fuels. https://www.agora-energiewende.de/fileadmin2/ Projekte/2017/SynKost_2050/Agora_SynKost_Study_EN_WEB.pdf. Accessed 14 Mar 2019

61. Imran Khan M (2017) Policy options for the sustainable development of natural gas as transportation fuel. Energy Policy 110:126-136. https://doi. org/10.1016/.enpol.2017.08.017

62. Yeh S (2007) An empirical analysis on the adoption of alternative fuel vehicles: the case of natural gas vehicles. Energy Policy 35(11):5865-5875. https://doi.org/10.1016/j.enpol.2007.06.012

63. Ecke J, Klein S, Klein SW et al. (2017) Klimaschutz durch Sektorkopplung: Optionen, Szenarien, Kosten. https://vng.de/sites/default/files/enervis_ klimaschutz_durch_sektorenkopplung.pdf. Accessed 14 Mar 2019

64. Moya JA, Pardo N (2013) The potential for improvements in energy efficiency and $\mathrm{CO} 2$ emissions in the EU27 iron and steel industry under different payback periods. J Clean Prod 52:71-83. https://doi.org/10.1016/j. jclepro.2013.02.028

65. Ranzani da Costa A, Wagner D, Patisson F (2013) Modelling a new, low CO2 emissions, hydrogen steelmaking process. J Clean Prod 46:27-35. https:// doi.org/10.1016/.j.jlepro.2012.07.045

66. Bassi AM, Yudken JS, Ruth M (2009) Climate policy impacts on the competitiveness of energy-intensive manufacturing sectors. Energy Policy 37(8):3052-3060. https://doi.org/10.1016/j.enpol.2009.03.055

67. Müller-Syring G, Henel M, Poltrum M et al (2018) Transformationspfade zur Treibhausgasneutralität der Gasnetze und Gasspeicher nach COP 21. energie | wasser-praxis, vol 10, pp 32-34

68. European Commission (2018) Commission welcomes final vote on energy performance of buildings: Press release. http://europa.eu/rapid/pressrelease_IP-18-3374_en.pdf. Accessed 14 Mar 2019

69. Stigka EK, Paravantis JA, Mihalakakou GK (2014) Social acceptance of renewable energy sources: a review of contingent valuation applications. Renew Sust Energ Rev 32:100-106. https://doi.org/10.1016/j.rser.2013.12.026

70. Wüstenhagen R, Wolsink M, Bürer MJ (2007) Social acceptance of renewable energy innovation: an introduction to the concept. Energy Policy 35(5): 2683-2691. https://doi.org/10.1016/j.enpol.2006.12.001

71. Valdés Lucas JN, Escribano Francés G, San Martín González E (2016) Energy security and renewable energy deployment in the EU: liaisons Dangereuses or virtuous circle? Renew Sust Energ Rev 62:1032-1046. https://doi.org/10. 1016/j.rser.2016.04.069

72. Huneke F, Perez Linkenheil C, Niggemeier M (2017) Kalte Dunkelflaute: Robustheit des Stromsystems bei Extremwetter. https://www.greenpeaceenergy.de/fileadmin/docs/pressematerial/170629_GPE_Studie_KalteDunkelflaute Energy-Brainpool.pdf. Accessed 14 Mar 2019

73. International Energy Agency (2017) World energy outlook 2017. https:// www.iea.org/Textbase/npsum/weo2017SUM.pdf. Accessed 14 Mar 2019

74. Balcombe P, Anderson K, Speirs J et al (2017) The natural gas supply chain: the importance of methane and carbon dioxide emissions. ACS Sustain Chem Eng 5(1):3-20. https://doi.org/10.1021/acssuschemeng.6b00144

75. Müller-Syring G, Große C, Wehling A et al. (2015) Methane emissions estimation method for the gas distribution grid (MEEM): requirements for a benefit-effort optimized method, potential for improvements and Need for Further Research. http://www.gerg.eu/public/uploads/files/publications/MEEM 180711_MEEM_DSO_Final_Report_end_signed.pdf. Accessed 14 Mar 2019

76. Zhang X, Myhrvold NP, Hausfather Z et al (2016) Climate benefits of natural gas as a bridge fuel and potential delay of near-zero energy systems. Appl Energy 167:317-322. https://doi.org/10.1016/j.apenergy.2015.10.016

77. E-Control (2018) Marktstatistik: Verbraucherstruktur. https://www.e-control. at/documents/20903/448569/MStErdGas-2017_JJ1Ver.xlsx/74ce7c6e-cfa96bc4-9be2-43a01a619a9c. Accessed 14 Mar 2019 
78. Council of European Energy Regulators (2018) Status review of renewable support schemes in Europe for 2016 and 2017. https://www.ceer.eu/ documents/104400/-/-/80ff3127-8328-52c3-4d01-0acbdb2d3bed. Accessed 14 Mar 2019

79. Winkler J, Magosch M, Ragwitz M (2018) Effectiveness and efficiency of auctions for supporting renewable electricity - what can we learn from recent experiences? Renew Energ 119:473-489. https://doi.org/10.1016/j. renene.2017.09.071

80. European Biogas Association (2018) Statistical Report 2018. http://biogas.org. rs/wp-content/uploads/2018/12/EBA_Statistical-Report-2018_EuropeanOverview-Chapter.pdf. Accessed 14 Mar 2019

81. Eurostat (2018) Complete energy balances-annual data. http://appsso. eurostat.ec.europa.eu/nui/show.do?dataset=nrg_110a\&lang=en. Accessed 14 Mar 2019

82. Wulf C, Linßen J, Zapp P (2018) Review of power-to-gas projects in Europe. Energy Procedia 155:367-378. https://doi.org/10.1016/j.egypro.2018.11.041

83. European Commission (2016) Optimal use of biogas from waste streams: an assessment of the potential of biogas from digestion in the EU beyond 2020. https://ec.europa.eu/energy/sites/ener/files/documents/ce_delft_ 3g84_biogas_beyond_2020_final_report.pdf. Accessed 14 Mar 2019

84. Ryckebosch E, Drouillon M, Vervaeren H (2011) Techniques for transformation of biogas to biomethane. Biomass Bioenergy 35(5):16331645. https://doi.org/10.1016/j.biombioe.2011.02.033

85. Boulamanti AK, Donida Maglio S, Giuntoli J et al (2013) Influence of different practices on biogas sustainability. Biomass Bioenergy 53:149-161. https://doi.org/10.1016/j.biombioe.2013.02.020

86. Searle S, Baldino C, Pavlenko N (2018) What is the role for renewable methane in European decarbonization?: briefing. https://www.theicct.org/ sites/default/files/publications/Role_Renewable_Methane_EU_20181016.pdf. Accessed 14 Mar 2019

87. Kovacs A et al. (2013) Proposal for a European biomethane roadmap. http:// european-biogas.eu/wp-content/uploads/2014/02/GGG_EuropeanBiomethane-Roadmap-final.pdf. Accessed 14 Mar 2019

88. European Commission (2016) EU reference scenario 2016: energy, transport and GHG emissions trends to 2050. https:/ec.europa.eu/energy/sites/ener/ files/documents/20160713\%20draft_publication_REF2016_v13.pdf. Accessed 14 Mar 2019

89. Speirs J, Balcombe P, Johnson E et al. (2018) A greener gas grid: what are the options? https:/www.sustainablegasinstitute.org/wp-content/uploads/ 2017/12/SGI-A-greener-gas-grid-what-are-the-options-WP3.pdf?noredirect=1. Accessed 14 Mar 2019

90. Siyal SH, Mentis D, Mörtberg U et al (2015) A preliminary assessment of wind generated hydrogen production potential to reduce the gasoline fuel used in road transport sector of Sweden. Int J Hydrog Energy 40(20):65016511. https://doi.org/10.1016/j.jijhydene.2015.03.108

91. Kötter E, Schneider L, Sehnke F et al (2016) The future electric power system: impact of power-to-gas by interacting with other renewable energy components. J Energy Storage 5:113-119. https://doi.org/10.1016/j.est.2015. 11.012

92. Perner J, Bothe D (2018) International aspects of a power-to-X roadmap: a report prepared for the world energy council. https://www.frontiereconomics.com/media/2642/frontier-int-ptx-roadmap-stc-12-10-18-finalreport.pdf. Accessed 14 Mar 2019

93. Blanco H, Nijs W, Ruf J et al (2018) Potential of power-to-methane in the EU energy transition to a low carbon system using cost optimization. Appl Energy 232:323-340. https://doi.org/10.1016/j.apenergy.2018.08.027

94. Simonis B, Newborough M (2017) Sizing and operating power-to-gas systems to absorb excess renewable electricity. Int J Hydrog Energy 42(34): 21635-21647. https://doi.org/10.1016/j.jijhydene.2017.07.121

95. Zappa W, Junginger M, van den Broek M (2019) Is a 100\% renewable European power system feasible by 2050? Appl Energy 233-234:1027-1050. https://doi.org/10.1016/j.apenergy.2018.08.109

96. ENTSO-G (2017) Transmission capacity map 2017. https://www.entsog.eu/ sites/default/files/2018-10/ Capacities\%20for\%20Transmission\%20Capacity\%20Map\%20RTS008_NS\%20\%20Final.xlsx. Accessed 14 Mar 2019

97. Menanteau P, Finon D, Lamy M-L (2003) Prices versus quantities: choosing policies for promoting the development of renewable energy. Energy Policy 31(8):799-812. https://doi.org/10.1016/50301-4215(02)00133-7

98. European Commission quarterly report on European gas markets: market observation of energy. https://ec.europa.eu/energy/sites/ener/files/ documents/quarterly_report_on_european_gas_markets_q2_2018.pdf. Accessed 14 Mar 2019

99. Horschig T, Adams PWR, Gawel E et al (2018) How to decarbonize the natural gas sector: a dynamic simulation approach for the market development estimation of renewable gas in Germany. Appl Energy 213: 555-572. https://doi.org/10.1016/j.apenergy.2017.11.016

100. Albrecht J, Laleman R, Vulsteke E (2015) Balancing demand-pull and supplypush measures to support renewable electricity in Europe. Renew Sust Energ Rev 49:267-277. https://doi.org/10.1016/j.rser.2015.04.078

101. Kitzing L, Mitchell C, Morthorst PE (2012) Renewable energy policies in Europe: converging or diverging? Energy Policy 51:192-201. https://doi.org/ 10.1016/j.enpol.2012.08.064

102. Schneider F, Volkert J (1999) No chance for incentive-oriented environmental policies in representative democracies? A public choice analysis. Ecol Econ 31:123-138

103. Agency for the Cooperation of Energy Regulators (2015) ACER/CEER annual report on the results of the monitoring the internal electricitiy and gas markets in 2015. https://www.acer.europa.eu/Official_documents/Acts_of_ the_Agency/Publication/ACER_Market_Monitoring_Report_2015.pdf. Accessed 14 Mar 2019

104. Agency for the Cooperation of Energy Regulators (2018) ACER/ CEER-annual report on the results of monitoring the internal electricity and natural gas markets in 2017 - electricity and gas retail markets volume. https://acer.europa.eu/Official_documents/Acts_of_the_Agency/Publication/ MMR\%202017\%20-\%20RETAIL.pdf. Accessed 14 Mar 2019

105. Eurostat (2016) Share of renewable energies on gross final energy use. http://ec.europa.eu/eurostat/tgm/table.do?tab=table\&init=1\&language= de\&pcode=t2020_31\&plugin=1. Accessed 14 Mar 2019

106. Verbruggen $A$, Lauber $V$ (2012) Assessing the performance of renewable electricity support instruments. Energy Policy 45:635-644. https://doi.org/10. 1016/j.enpol.2012.03.014

107. Fais B, Blesl M, Fahl U et al (2014) Comparing different support schemes for renewable electricity in the scope of an energy systems analysis. Appl Energy 131:479-489. https://doi.org/10.1016/j.apenergy.2014.06.046

108. Gawel E, Lehmann P, Purkus A et al (2017) Rationales for technologyspecific RES support and their relevance for German policy. Energy Policy 102:16-26. https://doi.org/10.1016/..enpol.2016.12.007

109. Rietmann N, Lieven T (2019) A comparison of policy measures promoting electric vehicles in 20 countries. In: Finger M (ed) The governance of smart transportation systems: towards new organizational structures for the development of shared, automated, electric and integrated mobility. Springer, Cham, Switzerland, pp 125-145

110. International Renewable Energy Agency (2018) Biogas for Road Vehicles: Technology brief. Accessed 03 Feb 2019
Ready to submit your research? Choose BMC and benefit from:
- fast, convenient online submission
- thorough peer review by experienced researchers in your field
- rapid publication on acceptance
- support for research data, including large and complex data types
- gold Open Access which fosters wider collaboration and increased citations
- maximum visibility for your research: over $100 \mathrm{M}$ website views per year
At BMC, research is always in progress.
Learn more biomedcentral.com/submissions 